\title{
Loan Loss Provisioning Rules, Procyclicality, and Financial Volatility
}

\author{
Pierre-Richard Agénor* and Roy Zilberman** \\ Final version: August 24, 2015 \\ Forthcoming, Journal of Banking and Finance
}

\begin{abstract}
Interactions between loan-loss provisioning regimes and business cycle fluctuations are studied in a dynamic stochastic general equilibrium model with credit market imperfections. With a specific provisioning system, provisions are triggered by past due payments. With a dynamic system, both past due payments and expected losses over the whole business cycle are accounted for, and provisions are smoothed over the cycle. Numerical experiments with a parameterized version of the model show that a dynamic provisioning regime can be highly effective in mitigating procyclicality of the financial system. The results also indicate that the combination of a credit gap-augmented Taylor rule and a dynamic provisioning system with full smoothing may be the most effective way to mitigate real and financial volatility associated with financial shocks.
\end{abstract}

JEL Classification Numbers: E31, E44, E52.

Keywords: Loan-loss provisioning systems; DSGE models; Financial volatility.

*School of Social Sciences, University of Manchester and Centre for Growth and Business Cycle Research; pierre-richard.agenor@manchester.ac.uk.**Department of Economics, Lancaster University Management School; r.zilberman@lancaster.ac.uk; corresponding author, Tel. +44 1524594034. 


\section{Introduction}

The global financial crisis has led to a renewed debate about both the nature and effectiveness of financial regulation, and the extent to which central banks should consider more explicitly financial stability objectives in the conduct of monetary policy. A key issue in this context has been the design of macroprudential instruments that help to mitigate the procyclicality of the financial system, that is, credit booms and busts that exacerbate the inherent cyclicality of lending - and consequently distort investment decisions, either by fueling excessive growth in credit or restricting access to bank finance. $^{1}$

Among these countercyclical instruments, capital buffers have attracted the most interest in policy circles and academic research. Under the Basel III regime for instance, central banks can now impose a countercyclical capital buffer ranging from 0 to 2.5 percent of risk-weighted assets; the buffer itself is related to excess growth in credit to the private sector, viewed as a good indicator of systemic risk (see Basel Committee on Banking Supervision (2011)). ${ }^{2}$ In academic research, a number of recent contributions have studied the performance of countercyclical capital rules in New Keynesian dynamic stochastic general equilibrium (DSGE) models; these contributions include Suh (2011), Agénor et al. (2013), and Angelini et al. (2014).

There has been also much discussion about the use of loan loss provisions as a countercyclical regulatory rule. In general, loan loss provisions can be classified into two main categories: a) specific provisions, which depend on expected losses on loans which have been identified as impaired or nonperforming, that is, if they have not been repaid a certain number of days (usually 90 days) past the due date; and $b$ ) general provisions, which depend on expected losses on loans which are not necessarily impaired but are likely to be in the future. ${ }^{3}$ In the United Kingdom for instance, general provisions are subjective but banks should take into account past experience and current economic

\footnotetext{
${ }^{1}$ See Athanasoglou et al. (2014) for an overview of the literature on the causes and consequences of procyclicality in banking.

${ }^{2}$ See Drehmann et al. (2010), Repullo and Saurina (2011), and Basel Committee on Banking Supervision (2012) for a more detailed discussion.

${ }^{3}$ Perez et al. (2008) note that general provisions usually rise during an economic upturn, as banks give out more loans and the demand for credit is high during this period. During a downturn, loans to riskier companies would incur larger loan losses as risks materialize, and therefore higher specific loan-loss provisions follow.
} 
conditions. Specific provisions are governed by International Accounting Standards (IAS) 39, which require domestic banks to adopt an incurred loss method of loan loss provisioning: this implies that provisions are set only once a loss has incurred. As a result, general provisions often represent only a small fraction of total provisions. More importantly, some observers have argued that IAS 39 accounting guidelines have been a predominant source of procyclicality in lending standards, because loan loss provisions tend to be essentially ex post. ${ }^{4}$ Indeed, with the incurred loss approach, the recognition of loan losses is delayed until borrowers actually default. Moreover, there are often restrictions on the tax deductibility of provisioning expenses, which tend to affect the cyclicality of bank profits, market valuations, and their funding costs. The result is that it can be difficult for a bank to increase provisions in an economic boom - even if it correctly judges that the future ability of its borrowers to repay has deteriorated. A possible consequence is that banks may reduce lending in recessions, thereby magnifying the impact of negative shocks (Beatty and Liao (2011), and Balla et al. (2012)).

This raises therefore the broader question of redesigning accounting principles (that is, switching from an incurred loss approach to an expected loss approach) to improve banking sector stability and mitigate procyclicality as well as systemic risk. Indeed, the Basel Committee continues to work with the International Accounting Standards Board (IASB) on the expected loss approach to loan loss provisioning. The view is that if dynamic provisions can take into account more credit information and anticipate and quantify better the expected losses associated with a loan portfolio, they would provide additional buffers and better incentives to mitigate procyclicality. This is the fundamental idea of dynamic provisioning rules, which have been used for some time in Spain. ${ }^{5}$ The Spanish system requires higher provisions when credit grows more than the historical average, thus linking provisioning to the credit and business cycle. This both discourages (although does not eliminate) excessive lending in booms and strengthens the banks for bad times. Studies that have attempted to evaluate

\footnotetext{
${ }^{4}$ In the United States, under the guidelines of the Generally Accepted Accounting Standards (GAAP), loan loss provisions should be established at a level that is adequate (but not excessive) to cover expected losses related to identified impaired loans and probable credit losses which have been incurred as of the balance sheet date. Thus, they are also essentially ex post in nature.

${ }^{5}$ The introduction of countercyclical provisions in Spain was facilitated by the fact that the design of accounting rules falls under the authority of the Central Bank of Spain.
} 
the performance of Spain's dynamic loan provisioning system include Saurina (2009), Caprio (2010), and Jiménez et al. (2012), and Fernández de Lis and Garcia-Herrero (2013); all concluded that although the provisioning scheme allowed banks to enter the downswing associated with the global financial crisis in more robust shape than they would have been otherwise, it is less clear that it had any material effect on the credit cycle or that it helped in any significant way to contain Spain's real estate bubble over the previous decade. Put differently, even though these systems may succeed in making banks more resilient-by increasing their capacity to absorb expected losses, in contrast to capital requirements - they appear to have limited effectiveness when it comes to restraining credit growth. ${ }^{6}$

This paper contributes to the debate on the performance of loan loss provisioning systems by embedding specific and dynamic provisioning rules in a New Keynesian DSGE model with monopoly banking and financial frictions. ${ }^{7}$ Somewhat surprisingly, there have been so far few attempts in the academic literature to address this issue. One of the few analytical contributions in this area is Bouvatier and Lepetit (2012), but their framework is not a full general equilibrium analysis. The model that we develop integrates elements of the DSGE framework developed in Agénor et al. (2013) with Bouvatier and Lepetit (2012) to study the interaction between bank provisioning rules, credit market imperfections, and business cycles in response to financial shocks. Our analysis considers the extent to which these interactions affect the procyclicality of the financial system as well as real and financial volatility.

More specifically, the commercial bank's loan pricing in the model is directly linked to loan loss provisions through two main transmission channels: the risk premium channel and the provisioning cost channel. The first channel is related to the fact that loan-loss provisions can either increase or lower the fraction of nonperforming loans, which in turn impacts the risk premium over the cost of borrowing from the central bank (the refinance rate). The provisioning cost channel is linked to the characteristics of loan-loss provisions reserves being invested in a safe asset (therefore entering positively the bank's profit function), and the direct cost of holding provisions which reduce

\footnotetext{
${ }^{6}$ See Wezel et al. (2012) for a further discussion. As noted in Wezel (2010), several countries in Latin America have introduced dynamic loan provisioning systems in recent years, but their experience is too recent to provide robust conclusions.

${ }^{7}$ Dynamic loan loss provisions are also referred to as "forward-looking" or "statistical" provisions. Because these terms can be confusing to some, we have chosen not to use them in this paper.
} 
bank profits and result in a higher loan rate. Our numerical experiments, based on a parameterized version of the model show that a dynamic provisioning regime can be highly effective in mitigating procyclicality of the financial system - regardless of the presence, or direction, of the risk premium channel. The results also indicate that the combination of a credit gap-augmented Taylor rule and a dynamic provisioning system with full smoothing may be a more effective way - in terms of minimizing a central bank policy loss function - to mitigate real and financial volatility, compared to a specific provisioning regime, coupled or not with an augmented Taylor rule. Moreover, the combination of a standard Taylor rule and a dynamic provisioning regime with full smoothing performs better than a credit-augmented rule combined with specific provisions.

The remainder of the paper is structured as follows. Section 2 describes the model. We keep the presentation relatively brief, given that several of its ingredients are described at length in Agénor and Alper (2012) and Agénor et al. (2013); instead, we focus on how the model presented here departs from those papers, especially with respect to bank balance sheets and provisioning rules. ${ }^{8}$ Key features of the steady-state equilibrium and the log-linearized model are characterized in Section 3. Parameterization is discussed in Section 4. The impulse response functions associated with our core experiment, a positive shock to nonperforming loans, are presented in Section 5. Sensitivity analysis is reported in Section 6. In Section 7, we consider a different but related experiment - whether it is optimal to combine a specific or dynamic provisioning system with a credit gap-augmented Taylor rule to mitigate real and financial volatility. The last section offers some concluding remarks and discusses some possible extensions of the analysis.

\section{The Model}

Consider an economy consisting of seven types of agents: forward-looking optimizing households, a final good (FG) firm, a continuum of intermediate good (IG) firms, a capital good (CG) producer, a single commercial bank, a government, and a central bank, which also acts as the bank regulator. The IG firms rent capital from the CG

\footnotetext{
${ }^{8}$ The present model differs from these previous contributions also to the extent that Calvo contracts are used for price setters. However, this difference plays no substantive role in the results.
} 
producer and employ labor to produce a unique good. These intermediate goods are then all combined by the FG firm, who produces a homogeneous final good, which, in turn, can be used for either consumption, investment or government spending.

The commercial bank receives deposits from households, supplies credit to the CG producer for investment financing, decides on the deposit rate and lending rate, and borrows from the central bank to cover any shortfall in funding. The supply of loans is perfectly elastic at the prevailing lending rate. The bank receives gross interest payments on investment loans and pays back principal plus interest on households' deposits and loans from the central bank. In addition, the bank holds loan-loss reserves. Provisioning rules are set by the central bank, and can be either (following common terminology in banking) specific or dynamic. In the former case, provisions are triggered by past due payments (or the fraction of nonperforming loans), which, in turn, depend on current economic conditions and the loan-loss provisions-loan ratio. Dynamic provisioning, by contrast, take into account both past due payments, as before, and expected losses over the whole business cycle; thus, provisions are smoothed over the cycle and are less affected by the current state of the economy and past due payments. We now turn to a more detailed description of the behavior of each agent in this economy.

\subsection{Households}

There is a continuum of households of measure 1, who consume, hold deposits and cash, invest in government bonds, and supply labor to IG firms.

The objective of the representative household is to maximize the utility function

$$
U_{t}^{i}=\mathbb{E}_{t} \sum_{t=0}^{\infty} \beta^{t}\left\{\frac{C_{t}^{1-\varsigma}}{1-\varsigma}-\frac{H_{t}^{1+\gamma}}{1+\gamma}+\eta_{x} \ln \left[\left(M_{t}^{H}\right)^{v} D_{t}^{1-v}\right]\right\},
$$

where $\mathbb{E}_{t}$ is the expectations operator conditional on the information available in period $t$, and $\beta \in(0,1)$ denotes the discount factor. The term $C_{t}$ denotes consumption of the final good at time $t$ while $H_{t}$ represents the time- $t$ hours devoted to labor by the household. Parameter $\varsigma$ stands for the inverse of intertemporal the elasticity of substitution in consumption, whereas $\gamma$ denotes the inverse of the Frisch elasticity of labor supply.

Households hold real cash balances $M_{t}^{H}$, which yield no return, and real bank 
deposits, $D_{t}$, which bear a net interest rate of $i_{t}^{D}$. Real cash balances combined with real bank deposits generate a composite monetary asset, given by a Cobb-Douglas form, $\left(M_{t}^{H}\right)^{v}\left(D_{t}\right)^{1-v}$, where $v \in(0,1)$. In addition, households invest in one-period government bonds, $B_{t}^{H}$, which yield a net interest of $i_{t}^{B}$. Hence, total gross repayments from holding deposits and government bonds in period $t-1$ (adjusted to real terms in period $t)$ are respectively given by $\left(1+i_{t-1}^{D}\right) P_{t-1} D_{t-1} / P_{t}$ and $\left(1+i_{t-1}^{B}\right) P_{t-1} B_{t-1}^{H} / P_{t}$, with $P_{t}$ denoting the price of the final good. ${ }^{9}$

At the start of period $t$, each household chooses the level of deposits, cash and government bonds, labor supply, for which it earns a factor payment of $P_{t}^{-1} W_{t} H_{t}$, where $W_{t}$ is the nominal wage. At the end of period $t$, households receive all profits from IG firms, $J_{t}^{I G}=\int_{0}^{1} J_{j, t}^{I G} d j$, and the CG producer, $J_{t}^{K}$, in the form of lump-sum transfers. They also receive all profits from the commercial bank, $J_{t}^{B}$, and pay a lump-sum tax given by $T_{t}$ in real terms. ${ }^{10}$

The representative households budget constraint is thus given by

$$
\begin{gathered}
C_{t}+D_{t}+B_{t}^{H}+M_{t}^{H} \leq\left(1+i_{t-1}^{D}\right) D_{t-1} \frac{P_{t-1}}{P_{t}}+\left(1+i_{t-1}^{B}\right) B_{t-1}^{H} \frac{P_{t-1}}{P_{t}} \\
+M_{t-1}^{H} \frac{P_{t-1}}{P_{t}}+\frac{W_{t} H_{t}}{P_{t}}+\int_{0}^{1} J_{j, t}^{I G} d j+J_{t}^{K}+J_{t}^{B}-T_{t} .
\end{gathered}
$$

Maximizing (1) subject to (2) with respect to $C_{t}, D_{t}, B_{t}^{H}, M_{t}^{H}$, and $H_{i}$, and taking interest rates and prices as given, yields

$$
\begin{gathered}
C_{t}^{-\varsigma}=\beta \mathbb{E}_{t}\left[C_{t+1}^{-\varsigma}\left(1+i_{t}^{B}\right) \frac{P_{t}}{P_{t+1}}\right], \\
D_{t}=\frac{\eta_{x}(1-v) C_{t}^{\varsigma}\left(1+i_{t}^{B}\right)}{i_{t}^{B}-i_{t}^{D}} \\
M_{t}^{H}=\frac{\eta_{x} v C_{t}^{\varsigma}\left(1+i_{t}^{B}\right)}{i_{t}^{B}} \\
H_{t}=\left(W_{t}^{R} C_{t}^{-\varsigma}\right)^{1 / \gamma}
\end{gathered}
$$

\footnotetext{
${ }^{9}$ The menu of financial assets considered here (cash, deposits, and bonds) is quite rich at the outset because, as is made clear later, it matters for the monetary transmission mechanism. Agénor and Alper (2012) provide a more detailed discussion of the importance of accounting for the money market in the determination of the bond rate and in understanding linkages between the real and financial sides.

${ }^{10}$ The final good firm earns zero profits in equilibrium, as noted below.
} 
where $W_{t}^{R}=W_{t} / P_{t}$ is the real wage. Equation (3) is the standard Euler equation. Equation (4) relates deposits positively to consumption and the deposit rate, and negatively to the rate of return on government bonds, whereas equation (5) relates the demand for cash positively to consumption and negatively with its opportunity cost, measured by the rate of return on bonds. Equation (6) defines labor supply.

\section{$2.2 \quad$ Final Good Firm}

A perfectly competitive representative FG firm assembles a continuum of intermediate goods $\left(Y_{j, t}\right.$ with $\left.j \in(0,1)\right)$, to produce final output, $Y_{t}$, using the standard Dixit-Stiglitz technology,

$$
Y_{t}=\left[\int_{0}^{1} Y_{j, t}^{\frac{\theta_{p}-1}{\theta_{p}}} d j\right]^{\frac{\theta_{p}}{\theta_{p}-1}}
$$

where $\theta_{p}>1$ denotes the constant elasticity of substitution between the differentiated intermediate goods. The FG firm chooses the optimal quantities of intermediate goods, $Y_{j, t}$, that maximize its profits, taking as given both the prices of the intermediate goods, $P_{j, t}$, and the final good price, $P_{t}$. This optimization problem yields the demand function for each intermediate good,

$$
Y_{j, t}=Y_{t}\left(\frac{P_{j, t}}{P_{t}}\right)^{-\theta_{p}}
$$

The zero-profit condition is imposed to obtain the final good price:

$$
P_{t}=\left[\int_{0}^{1} P_{j, t}^{1-\theta_{p}} d j\right]^{\frac{1}{1-\theta_{p}}} .
$$

\subsection{Intermediate Good Firms}

A continuum of IG producers, indexed by $j \in(0,1)$, operate in a monopolistic environment and use capital and labor to produce a unique good. The IG firm rents capital from the $\mathrm{CG}$ producer at the rate $r_{t}^{K}$, and employs labor, for which it pays a real wage of $W_{t}^{R}$. Each IG firm $j$ faces the Cobb-Douglas production function

$$
Y_{j, t}=A_{t} N_{j, t}^{1-\alpha} K_{j, t}^{\alpha}
$$

where $K_{j, t}$ denotes the amount of capital, $N_{j, t}$ labor supplied by the representative household to firm $j$, and $\alpha \in(0,1)$. The term $A_{t}$ represents a common economy wide technology shock which follows the $A R(1)$ process, $A_{t} / \tilde{A}=\left(A_{t-1} / \tilde{A}\right)^{v^{A}} \exp \left(\epsilon_{t}^{A}\right)$, where 
$v^{A}$ is the autoregressive coefficient, $\epsilon_{t}^{A}$ a normally distributed random shock with zero mean and a constant variance, and $\mathrm{a}^{{ }^{\prime \sim},}$ is used to denote a steady-state value. ${ }^{11}$

The IG firm solves a two stage pricing decision problem during period $t$. In the first stage, each IG producer minimizes the cost of renting capital and employing labor, taking wages and the rental price of capital as given. Specifically, the IG firm solves $\min _{N_{j, t}, K_{j, t}} W_{t}^{R} N_{j, t}+r_{t}^{K} K_{j, t}$, subject to (10). The optimal capital-labor ratio takes the familiar form $K_{j, t} / N_{j, t}=\alpha(1-\alpha)^{-1}\left(W_{t}^{R} / r_{t}^{K}\right)$, with the unit real marginal cost equal to

$$
m c_{j, t}=\frac{\left(W_{t}^{R}\right)^{1-\alpha}\left(r_{t}^{K}\right)^{\alpha}}{\alpha^{\alpha}(1-\alpha)^{1-\alpha} A_{t}} .
$$

In the second stage, each IG producer chooses the optimal price for its good. Here we assume familiar Calvo contracts, where a portion $\omega_{p} \in(0,1)$ firms keep their prices fixed while a portion of $1-\omega_{p}$ firms adjust prices optimally given the going marginal cost. The solution of this problem yields the familiar price equation ${ }^{12}$

$$
\frac{P_{t}^{*}}{P_{t}}=\left(\frac{\theta_{p}}{\theta_{p}-1}\right) \frac{\mathbb{E}_{t} \sum_{s=0}^{\infty} \omega_{p}^{s} \beta^{s} C_{t+s}^{-\varsigma} Y_{t+s} m c_{t+s}\left(\frac{P_{t+s}}{P_{t}}\right)^{\theta_{p}}}{\mathbb{E}_{t} \sum_{s=0}^{\infty} \omega_{p}^{s} \beta^{s} C_{t+s}^{-\varsigma} Y_{t+s}\left(\frac{P_{t+s}}{P_{t}}\right)^{\theta_{p}-1}},
$$

where $P_{t}^{*}$ is the optimal price chosen by firms adjusting their prices at period $t$ and $\theta_{p} /\left(\theta_{p}-1\right)$ represents the price mark-up.

\subsection{Capital Good Producer}

The CG producer owns all physical capital in the economy and uses a linear production function to produce capital goods. In order to produce these goods, the CG producer spends $I_{t}$ on the final good. For this purpose, it must pay for these goods in advance and borrows from the commercial bank at the beginning of the period. Thus, the real amount borrowed from the commercial bank, $L_{t}^{I}$, is ${ }^{13}$

$$
L_{t}^{I}=I_{t}
$$

\footnotetext{
${ }^{11}$ Results of supply shocks did not show significant differences across provisioning regimes and are not reported here to save space.

${ }^{12}$ We drop the subscript $j$ because all re-optimizing firms choose the same price so everything becomes time dependent.

${ }^{13}$ The assumption that all investment is financed through bank loans is consistent with the assumptions that all profits are distributed at the end of each period (which implies that retained earnings from any period cannot be used in the next period to fund capital accumulation) and that there are no alternatives to bank credit in the economy.
} 
The net interest rate charged by the bank for funding these investments is denoted by $i_{t}^{L}$. However, repayment is uncertain. If there is default, which occurs with probability $J_{t} \in(0,1)$, the CG producer loses the collateral that it pledges to secure the loan; collateral is given by $\kappa K_{t}$, where $\kappa \in(0,1)$ is the fraction of the capital stock that can be effectively pledged as collateral. If loans are repaid in full, an event that occurs with probability $1-J_{t}$, the total cost faced by the CG producer at the end of period $t$ is $\left(1+i_{t}^{L}\right) L_{t}^{I}$. Thus, expected repayment is $J_{t} \kappa K_{t}+\left(1-J_{t}\right)\left(1+i_{t}^{L}\right) L_{t}^{I}$.

To produce new capital, $K_{t+1}$, the $\mathrm{CG}$ producer uses the investment good together with the existing stock of capital from the previous period (net of depreciation). In addition, the CG producer incurs adjustment costs in producing new capital. Hence, capital evolves according to

$$
K_{t+1}=I_{t}+\left(1-\delta_{K}\right) K_{t}-\frac{\Theta_{K}}{2}\left(\frac{K_{t+1}}{K_{t}}-1\right)^{2} K_{t},
$$

where $\delta_{K} \in(0,1)$ denotes the constant rate of depreciation, and $\Theta_{K}>0$ the adjustment cost parameter. The new capital stock is then rented to the IG firms at the rate $r_{t}^{K}$.

The CG producer chooses the level of capital stock so as to maximize the value of discounted stream of dividend payments to households subject to equation (14). Specifically, defining $\mathbb{E}_{t} J_{t+1}^{K}=r_{t}^{K} K_{t}-J_{t} \kappa K_{t}-\left(1-J_{t}\right)\left(1+i_{t}^{L}\right) L_{t}^{I}$ as the CG producer's expected real profits at the end of period $t$, the optimization problem is, using (13) and (14),

$$
\begin{gathered}
\max _{K_{t+s+1}} \mathbb{E}_{t} \sum_{s=0}^{\infty} \beta^{s} \varphi_{t+s}\left\{r_{t+s}^{K} K_{t+s}-J_{t+s} \kappa K_{t+s}\right. \\
\left.-\left(1-J_{t+s}\right)\left(1+i_{t+s}^{L}\right)\left[K_{t+s+1}-\left(1-\delta_{K}\right) K_{t+s}+\frac{\Theta_{K}}{2}\left(\frac{K_{t+s+1}}{K_{t+s}}-1\right)^{2} K_{t+s}\right]\right\} .
\end{gathered}
$$

The first-order condition yields the arbitrage condition (see Appendix A):

$$
\begin{gathered}
\mathbb{E}_{t} r_{t+1}^{K}=\left(1-J_{t}\right)\left(1+i_{t}^{L}\right) \mathbb{E}_{t}\left\{\left[1+\Theta_{K}\left(\frac{K_{t+1}}{K_{t}}-1\right)\right]\left(1+i_{t}^{B}\right) \frac{P_{t}}{P_{t+1}}\right\} \\
+\mathbb{E}_{t}\left\{\kappa J_{t+1}-\left(1-J_{t+1}\right)\left(1+i_{t+1}^{L}\right)\left[\left(1-\delta_{K}\right)+\frac{\Theta_{K}}{2}\left[\left(\frac{K_{t+2}}{K_{t+1}}\right)^{2}-1\right]\right]\right\},
\end{gathered}
$$

which shows that the fraction of nonperforming loans affects the expected rate of return to capital (and thus the amount of capital produced), through its effect on expected repayment in both period $t$ and period $t+1$. 


\subsection{Commercial Bank}

\subsubsection{Balance Sheet and Loan-Loss Reserves}

At the start of period $t$ the commercial bank collects deposits from households in order to supply credit to the CG producer. The supply of credit is perfectly elastic at the prevailing loan rate and therefore the total amount of lending provided by the bank is given by equation (13). To fund any shortfall in funding, the commercial bank borrows an amount of $L_{t}^{B}$ from the central bank, for which it pays an interest rate of $i_{t}^{R}$. Moreover, the bank holds government bonds $B_{t}^{B}$ (a safe asset) which yields an interest of $i_{t}^{B} \cdot{ }^{14}$ As the loan portfolio takes into account expected loan losses, loan-loan reserves, $L L R_{t}$, are subtracted from total loans, consistent with standard practice (see Walter (1991) and Bouvatier and Lepetit (2012)). ${ }^{15}$ The bank's balance sheet in real terms is thus

$$
L_{t}^{I}-L L R_{t}+B_{t}^{B}=D_{t}+L_{t}^{B}
$$

The bank must also satisfy regulation in the form of setting loan-loss provisions (a flow), which are deducted from current earnings. As noted earlier, these provisions, which are defined in detail in the next section, can be based on either a specific or dynamic system. Loan-loss reserves (a stock) are accumulated partly by current loan-loss provisions and partly through past reserves through a geometric average specification. Specifically, to relate loan-loss provisions, $L L P_{t}$, and loan-loss reserves we assume that although accounting rules require provisioning requirements to be satisfied at the end of each period, the bank builds provisions up gradually during the period. This leads to a partial adjustment formulation, which takes the form

$$
L L R_{t}^{i}=\left(L L R_{t-1}^{i}\right)^{\rho_{L R}}\left(L L P_{t}^{i}\right)^{1-\rho_{L R}}
$$

where $i=S, D$ denotes specific and dynamic, respectively, and $\rho_{L R} \in(0,1)$ is a persistence parameter. The key advantage of this specification is that in the steady state, the parameter $\rho_{L R}$ plays no role; the stock of reserves is equal to the flow of provisions, regardless of the provisioning regime in place.

\footnotetext{
${ }^{14}$ We abstract from required reserves, given the purpose of this paper.

${ }^{15}$ In standard accounting, loan-loss provisions are defined as an estimation of probable loan losses for a current year and are charged as an expense, deducted from current profits (although, as noted earlier, these deductions are subject to restrictions in practice). Loan-loss reserves, by contrast, are a balance sheet item that depend on loan-loss provisions, accumulated charged off loans, and loan recoveries. The latter two components are ignored here for simplicity.
} 
In each period the bank invests its loan-loss reserves in the safe asset $\left(L L R_{t}=B_{t}^{B}\right)$ and earns a return of $i_{t}^{B}$ on them. Given this assumption, the balance sheet constraint (16) can be used to determine residually the level of borrowing from (or deposits at) the central bank:

$$
L_{t}^{B}=L_{t}^{I}-D_{t}
$$

\subsubsection{Alternative Provisioning Rules}

Provisioning rules are set by the central bank. We consider two specifications of loanloss provisions, which depend directly on the fraction of problem loans. First, a specific provisioning system, where loan-loss provisions are triggered by past due payments. Second, a dynamic provisioning system, where the bank makes provisions based on past due payments as well as expected losses over the whole business cycle.

To relate loan-loss provisions to the fraction of nonperforming loans (which in the present setting corresponds also to the default probability), we adopt a quasi-reduced form that emphasizes two sets of factors. First, we impose a negative correlation between provisions and cyclical output, which is the main stylized fact in the determination of specific provisions; see for instance Cavallo and Majnoni (2002), Laeven and Majnoni (2003), Bikker and Metzemakers (2005), and Nkusu (2011). ${ }^{16}$ This relationship is consistent with the idea that during economic booms, for instance, profits and cash flows tend to improve, implying that the fraction of nonperforming loans, and thus provisions, decrease.

Second, the fraction of problem loans (and thus loan-loss provisions) is related to the loan-loss reserves-lending ratio. On the one hand, this relationship can be negative, which is consistent with the idea that banks have a greater incentive to monitor their borrowers when they hold large loan-loss reserves (add-backs to regulatory bank capital, for instance). A greater degree of monitoring improves the ability of the bank to collect the full return on investment loans, thereby reducing the fraction of problem debt and the amount of required loan-loss provisions. If indeed loan-loss reserves can be treated as add-backs to bank capital (as outlined in the Basel Accords), holding more loan-

\footnotetext{
${ }^{16}$ Cavallo and Majnoni (2002) for instance examine empirically the policies of large commercial banks in various countries with regards to their provisions and income smoothing. These authors find that bankers on average smooth their income but do not create enough provisions during good times, implying that banks build provisions during recessions and not before. Therefore, the negative relationship between business cycles and loan-loss provisions amplify the effects of a recession.
} 
loss reserves relative to total loans allows banks to charge a lower spread on loans, where the spread depends positively on the fraction of nonperforming loans. ${ }^{17}$ This result is supported by the studies of Barth et al. (2004) and Coleman et al. (2006), among others. Furthermore, in the context of the recent financial crisis, Cole and White (2012) found evidence of a negative correlation between loan-loss reserves in 2007 and the probability of bank failure in 2009. Intuitively, loan-loss reserves may represent a source of strength against future losses, which can reduce the probability of a banking crisis associated with a higher fraction of nonperforming loans (see Cashin and Duttagupta (2008)).

On the other hand, the relationship between the fraction of problem loans and loanloss reserves may also be positive, as documented for instance in $\mathrm{Ng}$ and Roychowdhury (2011). They found that during the financial crisis of 2008-09, an increase in loan-loss reserves translated into a higher risk of bank default and a rise in nonperforming loans. ${ }^{18}$ Intuitively, holding more loan-loss reserves in the form of bank capital can lead bankers to extend more loans, even during a crisis period, thereby increasing the likelihood of moral hazard behavior and raising the possibility of default. Shrieves and Dahl (1992) also show a positive relationship between higher capital and investments in risky assets. Finally, Jin et al. (2011) also document a strong positive association between loan-loss provisions and the probability of bank failure for financially weak banks between 2007 and 2010. Bank failures, in turn, are often positively related with nonperforming loans (see Demirguc-Kunt and Detragiache (2005)), which implies that higher loan-loss reserves may indeed increase moral hazard behavior and induce a rise in nonperforming loans.

Given this description, the fraction of nonperforming loans, $J_{t}$, which is also the

\footnotetext{
${ }^{17}$ This monitoring incentive effect (which was discussed in the context of bank capital by Agénor et al. (2012)) is consistent with the fact that general provisions are recognized, up to a limit, as Tier 2 capital under Basel I and the standardised approach to Basel II. Under the Internal Rating Based (IRB) approach, all provisions attributable to IRB-rated exposures (including specific provisions) may be used to offset expected losses. Surplus provisions (those in excess of expected losses) may be counted as Tier 2 capital up to a limit of 0.6 percent of credit risk-weighted assets.

${ }^{18}$ However, Ng and Roychowdhury (2011) do not include bank characteristics prior to 2007, which could also explain bank failures in the subsequent years if banks had been financially weak for example. Cole and White (2012) do address these issues, thus making a comparison between these studies difficult.
} 
default probability if default is random, is therefore defined as

$$
J_{t}=j_{0}\left(\frac{Y_{t}}{\tilde{Y}}\right)^{\omega_{Y}}\left(\frac{L L R_{t} / L_{t}^{I}}{\overparen{L L R} / \tilde{L}^{I}}\right)^{\omega_{L R}} \varepsilon_{t}^{J}
$$

where $\omega_{Y}<0, \omega_{L R} \gtrless 0$. The term $j_{0}>0$ represents the steady-state fraction of nonperforming loans, whereas the term $Y_{t} / \tilde{Y}$ (where $\tilde{Y}$ is the steady-state value of output) denotes the cyclical component of output. We also relate the fraction of nonperforming loans to deviations in the loan-loss reserves-loan ratio. As explained earlier, the elasticity $\omega_{L R}$ can be either negative or positive, depending on whether loan-loss reserves lead to increased bank monitoring or induce moral hazard behavior. Because of this ambiguity, in the simulations reported later we will use $\omega_{L R}=0$ as the benchmark case and will consider positive and negative values of $\omega_{L R}$ for sensitivity analysis. The random variable $\varepsilon_{t}^{J}$ captures nonsystematic shocks to nonperforming loans, that is, shocks that are not directly associated with movements in the output gap, collateral, and loan-loss reserves. It follows an $A R(1)$ process, $\varepsilon_{t}^{J}=\left(\varepsilon_{t-1}^{J}\right)^{v^{J}} \exp \left(\epsilon_{t}^{J}\right)$, where $v^{J} \in(0,1)$ and $\epsilon_{t}^{J}$ a normally distributed shock with zero mean and a constant variance.

Turning now to the different types of provisioning rules, we first model the specific provisioning system (denoted by superscript $S$ ), where the bank evaluates its credit risk exposure on current nonperforming loans. Therefore, and similar to Bouvatier and Lepetit (2012), we define loan-loss provisions in a specific system as

$$
L L P_{t}^{S}=l_{0} J_{t} L_{t}^{I}
$$

where $l_{0}$ is the steady-state fraction (or average fraction over a whole business cycle) of nonperforming loans $\left(J_{t} L_{t}^{I}\right)$, which are covered by loan-loss provisions in period $t$. Put differently, $l_{0}$ is the coverage ratio, measured as loan-loss provisions divided by the fraction of nonperforming loans.

The alternative specification for loan-loss provisions is the dynamic provisioning system (denoted by superscript $D$ ), in which the bank makes provisions related to the current percentage of nonperforming loans (as before) and the evaluation of the latent risk over the whole business cycle. Specifically, following again Bouvatier and Lepetit (2012), statistical loan-loss provisions can be written as

$$
L L P_{t}^{D}=l_{0} J_{t} L_{t}^{I}+\lambda\left(\tilde{J}-J_{t}\right) l_{0} L_{t}^{I}
$$


where $\lambda \in(0,1)$ denotes the degree of loan-loss provisions smoothing under the dynamic system, and $\tilde{J}$ the steady-state value of the fraction of nonperforming loans (or the longrun evaluation of latent risk by the commercial bank). Thus, the difference between the two formulations relates to whether $\lambda=0$ or $0<\lambda \leq 1$. During an economic expansion, where the short-run value of current nonperforming loans, $J_{t}$, is lower than the estimation of the latent risk over the whole cycle, $\tilde{J}$, the commercial bank can build up provisions, above and beyond specific provisions. Therefore, taking into account expected losses over the business cycle offsets the short-run impact of problem loans on current provisions. In what follows we will refer to the case where $\lambda=1$ as full smoothing, in the sense that any deviation in the fraction of nonperforming loans from its steady-state value is completely reflected in the calculation of total provisions.

\subsubsection{The Bank's Optimization Problem}

Given the structure of deposit and loan contracts, the bank's decision problem can be solved period by period. Specifically, in each period the bank sets ex ante the (gross) deposit and lending rates in order to maximize the expected value of end-of-period real profits, defined as ${ }^{19}$

$$
\begin{aligned}
\mathbb{E}_{t} J_{t+1}^{B}= & \left(1-J_{t}\right)\left(1+i_{t}^{L}\right) L_{t}^{I}+J_{t}\left(\kappa K_{t}\right)+\left(1+i_{t}^{B}\right) L L R_{t}^{i} \\
& -\left(1+i_{t}^{D}\right) D_{t}-\left(1+i_{t}^{R}\right) L_{t}^{B}-L L P_{t}^{i},
\end{aligned}
$$

subject to the loan demand function of the CG producer (13), loans from the central bank (18), the fraction of nonperforming loans (19), and the type of provisioning system $L L P_{t}^{i}$ with $i=S, D$ (equations (20) or (21)).

The term $1-J_{t}$ stands for the fraction of loans that are repaid to the commercial bank. In case of an increased likelihood of default, when loans move to the nonperforming loans category (problem loans), the bank is partly compensated by seizing collateral, given by $J_{t} \kappa K_{t}$. Loan-loss provisions, $L L P_{t}^{i}$, are deducted from the bank's profits but also enter partly as gross income because loan-loss reserves are invested in government bonds $\left(L L R_{t}=B_{t}^{B}\right)$. The other terms in (22) are standard.

\footnotetext{
${ }^{19}$ To avoid corner solutions we assume that $\kappa K_{t} \leq\left(1+i_{t}^{L}\right) L_{t}^{I}$. In a previous version of this paper we also accounted (as in Bouvatier and Lepetit (2012)) for recognized losses or charged-off loans, that is, loans that are in actual default and removed from the bank's balance sheet. However, we chose to ignore them in the present version, because they did not add much additional insight to the analysis.
} 
In solving the maximization problem defined in (22), the bank takes as given the fraction of nonperforming loans, the value of collateral, and the refinance rate. The first-order conditions with respect to the deposit and loan rates are given respectively by (see Appendix B):

$$
\begin{gathered}
1+i_{t}^{D}=\frac{1+i_{t}^{R}}{1+\eta_{D}^{-1}} \\
1+i_{t}^{L}=\frac{\left(1+\eta_{L}^{-1}\right)^{-1}}{1-J_{t}}\left\{\left(1+i_{t}^{R}\right)+\frac{\partial L L P_{t}^{i}}{\partial L_{t}^{I}}-\left(1+i_{t}^{B}\right) \frac{\partial L L R_{t}^{i}}{\partial L_{t}^{I}}\right\},
\end{gathered}
$$

where $\eta_{D}$ and $\eta_{L}$ are constant interest elasticities of deposits and loan demand, respectively, and, from (17),

$$
\frac{\partial L L R_{t}^{i}}{\partial L_{t}^{I}}=\left(L L R_{t-1}^{i}\right)^{\rho_{L R}}\left(1-\rho_{L R}\right)\left(L L P_{t}^{i}\right)^{-\rho_{L R}} \frac{\partial L L P_{t}^{i}}{\partial L_{t}^{I}}
$$

with from (20) and (21), the marginal provisioning cost under each regime is given by

$$
\begin{gathered}
\frac{\partial L L P_{t}^{S}}{\partial L_{t}^{I}}=l_{0} J_{t} \\
\frac{\partial L L P_{t}^{D}}{\partial L_{t}^{I}}=(1-\lambda) l_{0} J_{t}+\lambda l_{0} \tilde{J} .
\end{gathered}
$$

Equation (23) indicates that the deposit rate is set as a markup over the refinance rate. $^{20}$ Equation (24) describes the lending rate equation; it is the key channel through which loan-loss provisions affect the financial sector. Intuitively, there are two channels at play in the determination of the loan rate. The first is a risk premium channel, which is related to the fact that the bank expects to receive back only a fraction of its loans; the marginal return on loans is therefore only $\left(1-J_{t}\right)\left(1+i_{t}^{L}\right)$. Equivalently, the bank internalizes the fact that the fraction of nonperforming loans is positive, and charges a higher loan rate as a result.

The second effect is the (marginal) cost channel, which consists of several components. First, there is a direct cost channel associated with changes in the cost of borrowing from the central bank, $1+i_{t}^{R}$, which the bank mechanically passes on to borrowers. Second, there is what we may call (to fix ideas) a provisioning cost channel, which is related to the composite term $\left(\partial L L P_{t}^{i} / \partial L_{t}^{I}\right)-\left(1+i_{t}^{B}\right)\left(\partial L L R_{t}^{i} / \partial L_{t}^{I}\right)$ in $(24)$. This term results from the relationship between loan-loss reserves invested in a safe

\footnotetext{
${ }^{20}$ Note that $i_{t}^{D}<i_{t}^{R} \forall t$, implying that the commercial bank always absorbs all deposits made by households.
} 
asset and the direct cost effect of raising provisions. Intuitively, a one unit increase in lending raises the flow of provisions by $\partial L L P_{t}^{i} / \partial L_{t}^{I}$; this is costly for the bank (provisions reduce profits) and accordingly it adjusts the loan rate upward. However, at the same time, because one unit of loan-loss reserves yield a gross return of $1+i_{t}^{B}$, the commercial bank can lower the cost of borrowing in response to an increase in provisions. This result implies that if $\partial L L R_{t}^{i} / \partial L_{t}^{I}>0$, a fall in the bond rate for instance will tend to be contractionary. ${ }^{21}$ However, in general whether the composite term $\left(\partial L L P_{t}^{i} / \partial L_{t}^{I}\right)-\left(1+i_{t}^{B}\right)\left(\partial L L R_{t}^{i} / \partial L_{t}^{I}\right)$ is positive or negative cannot be ascertained a priori; the way the provisioning rule determines the behavior of the loan rate depends on how the fraction of nonperforming loans affects the marginal cost of provisions, which in turn varies across provisioning regimes. As discussed later, the effect of provisions on the loan rate is determined largely by the persistence parameter $\rho_{L R}$.

\subsection{Central Bank}

The central bank's assets consist of loans to the commercial bank and holdings of government bonds, $B_{t}^{C}$, whereas its liabilities are given by currency in circulation, $M_{t}^{S}$ :

$$
L_{t}^{B}+B_{t}^{C}=M_{t}^{S}
$$

The central bank targets the short term policy rate, $i_{t}^{R}$, using a standard (deterministic) Taylor-type rule:

$$
\frac{1+i_{t}^{R}}{1+\tilde{\imath}^{R}}=\left(\frac{1+i_{t-1}^{R}}{1+\tilde{\imath}^{R}}\right)^{\phi}\left[\left(\frac{Y_{t}}{\tilde{Y}}\right)^{\phi_{Y}}\left(\frac{\pi_{t}}{\pi^{T}}\right)^{\phi_{\pi}}\right]^{1-\phi},
$$

where $\pi^{T}$ is the target inflation rate, $Y_{t} / \tilde{Y}$ is again the cyclical component of output, $\phi \in(0,1)$ the degree of interest rate smoothing and $\phi_{Y}, \phi_{\pi}>0$.

Central bank income generated by supplying loans to the commercial bank and by holding government bonds are transferred to the government at the end of the period.

\subsection{Government}

The government spends $G_{t}$ on the final good and issues one period risk-free bonds, held by households, the commercial bank, and the central bank. The government collects

\footnotetext{
${ }^{21}$ Bouvatier and Lepetit (2012), in their partial equilibrium model, do not account for a direct impact of the interest rate on loan-loss reserves on the loan rate as we do here. As discussed later, this channel does matter when comparing the performance of specific and dynamic provisioning systems.
} 
lump-sum taxes on households, pays interest to them on their holding of government bonds, and receives all interest income made by the central bank. Thus, its budget constraint in real terms is

$$
T_{t}+i_{t-1}^{R} L_{t-1}^{B} \frac{P_{t-1}}{P_{t}}+i_{t-1}^{B} B_{t-1}^{C} \frac{P_{t-1}}{P_{t}}+B_{t}=\left(1+i_{t-1}^{B}\right) B_{t-1} \frac{P_{t-1}}{P_{t}}+G_{t},
$$

where $B_{t}=B_{t}^{H}+B_{t}^{B}+B_{t}^{C}$. Government spending is set as a constant fraction of output of the final good:

$$
G_{t}=\mu Y_{t}
$$

where $\mu \in(0,1)$.

\subsection{Market-Clearing Conditions}

In what follows we assume that the government maintains a balanced budget by adjusting lump-sum taxes, while keeping its overall stock of bonds constant at $\bar{B}$. Moreover, the stock of bonds held by the central bank is also assumed to be constant at $\bar{B}^{C} .^{22}$

In a symmetric equilibrium, households are identical and IG firms produce the same output and set equal prices. Therefore, $K_{j, t}=K_{t}, N_{j, t}=N_{t}, Y_{j, t}=Y_{t}$ and $P_{j, t}=P_{t}$ for all $j \in(0,1)$.

The supply of loans by the commercial bank and the supply of deposits by households are assumed to be perfectly elastic at the prevailing interest rates and therefore markets for loans and deposits always clear. The goods market clearing condition is

$$
Y_{t}=C_{t}+I_{t}+G_{t}
$$

Loans are made in the form of cash. Therefore, the equilibrium condition in the currency market is obtained by equating supply and total demand for cash (by households and firms),

$$
M_{t}^{S}=M_{t}^{H}+L_{t}^{I} .
$$

After substituting equations (4), (5), (18), and (28), equation (33) can be solved for the equilibrium bond rate, $i_{t}^{B}$.

\footnotetext{
${ }^{22}$ Walras's law ensures that the market for bonds always clears.
} 


\section{Steady State and Log-Linearization}

Many of the steady-state solutions of the model are familiar, so we focus here only on some of the financial variables. Under the assumption of zero inflation in the steady state, the long-run value of the bond rate is equal to $\tilde{\imath}^{B}=\beta^{-1}-1$. In addition, to ensure that the commercial bank has no incentive to borrow from the central bank in order to invest in government bonds, we impose $\tilde{\imath}^{R}=\tilde{\imath}^{B}$. This equality From (23), this result implies also that $\tilde{\imath}^{B}>\tilde{\imath}^{D}$.

In the steady state, loan-loss reserves and loan-loss provisions under both the specific and dynamic systems are equal to

$$
\widetilde{L L R}=\widetilde{L L P}=l_{0} \tilde{J} \tilde{L}^{I}
$$

Hence, the lending rate equation in the long run is also the same under both provisioning rules:

$$
1+\tilde{\imath}^{L}=\frac{\left(1+\eta_{L}^{-1}\right)^{-1}}{1-\tilde{J}}\left[\left(1+\tilde{\imath}^{R}\right)-\tilde{\imath}^{B} l_{0} \tilde{J}\right] .
$$

The log-linearized equations of the model - in terms of percentage point deviations for price inflation and interest rate variables, and log-deviations for the rest of the variables - around a non-stochastic steady state are presented in detail in Appendix C. ${ }^{23}$ Again, many of these equations are familiar; the New Keynesian Phillips Curve for instance, which determines the price inflation rate, is given by

$$
\hat{\pi}_{t}=\beta \mathbb{E}_{t} \hat{\pi}_{t+1}+\frac{\left(1-\omega_{p}\right)\left(1-\omega_{p} \beta\right)}{\omega_{p}} \widehat{m c}_{t}
$$

where log-linearized variables are denoted by a hat.

More relevant for the issue at hand, the log-linearized equations representing loanloss provisions in the specific and dynamic regimes are respectively given by

$$
\begin{gathered}
\widehat{L L P_{t}^{S}}=\widehat{J}_{t}+\widehat{L_{t}^{I}}, \\
\widehat{L L P_{t}^{D}}=(1-\lambda) \widehat{J}_{t}+\widehat{L_{t}^{I}} .
\end{gathered}
$$

The log-linear equation that defines the fraction of nonperforming loans is represented by

$$
\left.\widehat{J}_{t}=\omega_{Y} \widehat{Y}_{t}+\omega_{L R} \widehat{\left(L L P_{t}^{i}\right.}-\widehat{L_{t}^{I}}\right)+\widehat{\varepsilon_{t}^{J}} .
$$

\footnotetext{
${ }^{23}$ Log-linearized net interest rates are used as an approximation for log-linearized gross interest rates.
} 
From (17),

$$
\widehat{L L R_{t}^{i}}=\rho_{L R} \widehat{L L R_{t-1}}+\left(1-\rho_{L R}\right) \widehat{L L P_{t}^{i}}
$$

Using this result, the loan rate in its log-linear form is given by

$$
\begin{gathered}
(1-\tilde{J})\left(1+\tilde{\imath}^{L}\right) \widehat{i_{t}^{L}}=\left(1+\tilde{\imath}^{R}\right) \widehat{i_{t}^{R}}+\left[1-\left(1+\tilde{\imath}^{B}\right)\right] \tilde{J}\left(\frac{\widehat{\partial L L P_{t}^{i}}}{\partial L_{t}^{I}}\right) \\
-\left(1+\widetilde{i}^{B}\right) \tilde{J}\left[\widehat{i_{t}^{B}}-\rho_{L R}\left(\widehat{L L P_{t}^{i}}-\widehat{L L R_{t-1}^{i}}\right)\right]+\tilde{J}\left(1+\tilde{\imath}^{L}\right) \widehat{J}_{t}
\end{gathered}
$$

where

$$
\frac{\widehat{\partial L L P_{t}^{S}}}{\partial L_{t}^{I}}=\widehat{J}_{t}, \quad \frac{\partial \widehat{L L P_{t}^{D}}}{\partial L_{t}^{I}}=(1-\lambda) \widehat{J}_{t} .
$$

From the above equations, and as noted earlier, changes in the fraction of nonperforming loans and the type of provisioning system impact directly the loan rate. In turn, the cost of loans is passed to the rental rate of capital, which changes the marginal cost of producing intermediate goods and thus, all else equal, the inflation rate and output. Thus, the key channel through which the provisioning regime influences the link between the financial and real sides of the economy is through the cost of borrowing.

\section{Parameterization}

The baseline parameterization of the model is summarized in Table 1. Parameters that characterize tastes, preferences, technology, adjustment costs, the fraction of firms that reset their prices, capital depreciation, and the Taylor rule, are all standard in the literature. We therefore focus on in what follows on the parameters that are new to this model.

For the variables related to the household, we set $\eta_{x}$, the preference of parameter for the composite monetary asset, at 0.01 , and the share parameter in the index of cash holding, $v$, at 0.40 . The combination of these values yields a deposit plus cash to output ratio of 90 percent, which is on average the ratio of liquid assets to GDP observed in the European Union (see Levine et al. (2000) and Hou et al. (2012)).

With respect to the parameters associated with the fraction of nonperforming loans and its relationship with loan-loss provisions, we calibrate the elasticity of the percentage of problem loans with respect to the output gap, $\omega_{Y}$, at -0.2 . Although not 
directly comparable, this value is consistent with the empirical results of Bikker and Metzemakers (2005) using OECD data and Nkusu (2011) for advanced economies, both of which focus on the impact of GDP growth on loan-loss provisions. ${ }^{24}$ Nkusu (2011) for instance found an elasticity of -0.16 between real GDP growth and nonperforming loans.

As noted earlier, empirical studies report conflicting effects regarding the impact of the loan loss reserves-loan ratio on the fraction of nonperforming loans. We therefore use as a benchmark case $\omega_{L R}=0$ and will consider later on negative and positive values of $\omega_{L R}$. Moreover, when examining the impact of the dynamic loan loss provisioning rule, we set the smoothing coefficient, $\lambda$, at 0.8 , implying therefore a high but less than integral smoothing effect of loan loss provisions over the cycle. In all experiments the steady-state fraction of nonperforming loans, $j_{0}$, is 0.03 , consistent with data for advanced economies. The persistence parameter, $\rho_{L R}$, is set at a relatively high value of 0.8 initially (to capture the case where loan-loss reserves are driven mainly by past reserves), and sensitivity analysis is conducted later on. Finally, the government's share of spending out of final output, $\mu$, is set to 0.30 , which corresponds to the average ratio of the government expenditures-GDP ratio for OECD countries between 2007-09 (see OECD (2011)). From (32), private absorption (consumption and investment) is thus 70 percent of output.

The above parameterization implies that the steady-state values of the loan rate, the bond rate, and the rate of return on physical capital are 5.15 percent, 1.01 percent, and 2.47 percent, respectively. These values are well within the range observed for industrialized countries.

\section{Shock to Nonperforming Loans}

The core experiment that we examine is a financial shock, taking the form of a temporary 10 percent relative increase in the fraction of nonperforming loans, $\varepsilon_{t}^{J}$, that is, an increase in $J$ from 0.03 to 0.033 (or 30 basis points). We compare the performance of specific and dynamic provisioning rules $(\lambda=0$ and $\lambda=0.8$, respectively) in the benchmark case where $\omega_{L R}=0$.

\footnotetext{
${ }^{24}$ Note that in a number of econometric studies output growth is replaced by the output gap, with little impact on the results; see for instance Packer and Zhu (2012).
} 
Figure 1 shows the impulse response functions of the main variables of the model following a 10 percent increase in the fraction of nonperforming loans, $\varepsilon_{t}^{J}$, under a specific provisioning system (blue line) and a dynamic provisioning system (dashed red line). The direct effect of an exogenous increase in the fraction of nonperforming loans is an immediate rise in the loan rate, stemming from the risk premium channel; the commercial bank sets a higher loan rate when the perception of risk is higher. The rise in the lending rate lowers investment loans and the rate at which physical capital is accumulated. While by itself a lower capital stock tends to increase the rental rate of capital, the general equilibrium effect, accounting for the rise in current and expected nonperforming loans, is to reduce it. As a result, the marginal cost of production falls as well. Moreover, the drop in employment lowers real wages such that the marginal costs and consequently inflation fall upon the impact of the shock.

The sharp fall in investment induced by the rise in the loan rate, along with the drop in the capital stock, leads to a sharp contractionary effect on output. Because both output and inflation fall, the policy rate, which is determined by the Taylor rule, falls as well. The deposit rate, set as a mark down on the policy rate, drops also, resulting in lower demand for deposits and hence (all else equal) an increase in borrowing from the central bank and an expansion in the monetary base. To raise the demand for cash and restore equilibrium in the money market, the bond rate must therefore decrease, which, through intertemporal substitution, results in a higher level of consumption in the short run. Given our calibration the drop in investment dominates the rise in consumption and output, relative to its steady-state level, drops initially. ${ }^{25}$ This in turn tends to amplify the response of the fraction of nonperforming loans, leading to a higher loan rate.

The key channels through which changes in provisions affect the real economy come from the relationship between loan-loss provisions acting as reserves invested in a safe asset and the direct cost effect of holding provisions - the combination of which we earlier referred to as the provisioning cost channel. As shown in Figure 1, following a rise in the percentage of nonperforming loans, the loan-loss provisions-loan ratio increases. This leads to a higher loan rate through the direct cost effect of raising provisions - regardless of the provisioning regime. ${ }^{26}$ However, as also shown in the

\footnotetext{
${ }^{25}$ This outcome is quite reasonable, given the nature of the shock.

${ }^{26}$ Note that the fraction of nonperforming loans doesn't change much across provisioning regimes,
} 
figure, dynamic provisions significantly mitigate the increase in the loan rate, and thus fluctuations on the real side of the economy.

Intuitively, with a dynamic provisioning rule, loan-loss provisions are smoothed over the cycle in such a way that total provisions are less affected by the current fraction of nonperforming loans. During a downturn, when the current proportion of nonperforming loans increases and exceeds its steady-state value, the commercial bank can draw down its loan loss reserves. This is achieved over time by reducing the rate at which it accumulates provisions to levels below those required by specific provisions. Thus, as long as the shock persists and the economy displays monotonic behavior, total provisions will increase by less than specific provisions. In turn, this mitigates the increase in the loan rate and dampens the response of investment, output and inflation. A dynamic provisioning regime therefore attenuates the procyclicality of the financial system.

Table 2 compares the asymptotic standard deviations (theoretical moments) and the relative standard deviations of key variables of a specific provisioning system $(\lambda=0)$, a moderate dynamic prvisioning system $(\lambda=0.5)$ and a highly dynamic system $(\lambda=0.8)$ following a financial shock. The relative standard deviations are calculated relative to the standard deviations of the specifc provisioning system. The table confirms indeed that dynamic provisioning is highly effective in terms of mitigating the volatility of key macroeconomic and financial variables - independently of whether loan-loss reserves reduce or increase the fraction of nonperforming loans.

\section{Sensitivity Analysis}

To assess the robustness of the previous results, we focus on two experiments: changes in the persistence parameter in the loan-loss reserve specification, and nonzero values of the parameter that captures the impact of loan-loss reserves on nonperforming loans.

\subsection{Change in Reserve Persistence Parameter}

Consider first the case where $\rho_{L R}$ takes a value of 0.95 , higher than in the benchmark case. The results of this experiment are shown in Figure 2. They are fairly similar to because it is related to output through a relatively small value of $\omega_{Y}=0.2, \omega_{L R}=0.0$, and it is driven mainly by the shock to nonperforming loans. 
those discussed previously; a closer inspection of the impulse response functions shows that the performance of the dynamic provisioning regime, in terms of mitigating macroeconomic and financial instability is improved. Intuitively, as can be inferred from (25), the higher $\rho_{L R}$ is, the closer $\partial L L R_{t}^{i} / \partial L_{t}^{I}$ will be to zero; the effect of provisions on the loan rate then depend essentially on changes in $\partial L L P_{t}^{i} / \partial L_{t}^{I}$. A comparison of (26) and (27) shows that, with $0<\lambda \leq 1$, the dynamic provisioning regime is more effective in mitigating an increase in the loan rate. The closer $\rho_{L R}$ and $\lambda$ are to unity, the more effective the regime is.

Alternatively, consider the case where $\rho_{L R}=0.15$, where changes in loan-loss reserves are mainly driven by changes in current provisions. The results are shown in Figure 3. With the exception of the loan-loss provision-loan ratio, there are essentially no meaningful differences between the two provisioning regimes - even though $\lambda \leq 1$. Put differently, the reason why a dynamic provisioning regime is more effective in terms of macroeconomic and financial stability is because it helps to mitigate changes in the stock of loan-loss reserves in the course of the business cycle. This is precisely the argument that is typically invoked in practice.

\subsection{Monitoring Incentive and Moral Hazard Effects}

The foregoing discussion has focused on a comparison of the performance of specific and dynamic provisioning regimes in the absence of any effect of the loan-loss reservesloan ratio on the fraction of nonperforming loans, that is, with $\omega_{L R}=0$. It was argued that this is a reasonable benchmark given the conflicting results regarding the sign of this parameter in the empirical literature.

We now consider the case where $\omega_{L R}$ is either negative (the "monitoring incentive" effect dominates) or positive (the "moral hazard" effect dominates). In both cases we continue to assume that $\rho_{L R}=0.8$.

\subsubsection{Monitoring Incentive Effect}

Figure 4 shows the results when $\omega_{L R}$ takes a small negative value, -0.15 . There is now an additional channel through which changes in provisions affect the real economy: the monitoring incentive effect implies that a higher ratio of loan-loss reserves to loans reduces the fraction of nonperforming loans, and thereby mitigates the initial rise in 
the lending rate following the financial shock.

As shown earlier, following a rise in the percentage of nonperforming loans, the loanloss provisions-loan ratio increases, which from the provisioning cost channel increases the loan rate. With a monitoring incentive effect, the rise in the loan-loss provisionsloan ratio helps to mitigate the response of the loan rate through its impact on the fraction of nonperforming loans, that is, through the risk premium channel. Hence, under the specific system, the provisioning cost channel and the risk premium channel work in opposite directions. But again, a visual inspection of the results displayed in Figure 4 show that the dynamic provisioning regime - despite being associated with a slight increase in the fraction of nonperforming loans-performs better than the specific provisioning regime in terms of mitigating the procyclicality of the financial system. This is because the cost effect of provisions dominates the risk premium channel associated with the stock of reserves. ${ }^{27}$

\subsubsection{Moral Hazard Effect}

Figure 5 shows the results when $\omega_{L R}$ takes a small positive value, 0.15 . The additional channel that is considered now is the moral hazard effect, which implies that a higher ratio of loan-loss reserves to loans raises the fraction of nonperforming loans. As opposed to the previous case, under the moral hazard scenario, a higher loan-loss provisions to loan ratio amplifies the rise in the loan rate via the risk premium channel. Therefore, combined with the direct cost effect of raising provisions, both of these channels amplify the rise in the cost of borrowing under the specific provisioning regime. Therefore, dynamic provisions unambiguously dampen the increase in the lending rate and can promote macroeconomic and financial stability.

In sum, this sensitivity analysis shows that a nonzero value of $\omega_{L R}$ in absolute value magnifies the differences between specific and dynamic provisioning systems, but it does not change relative effectiveness of these two regimes in response to financial shocks. What is important, for understanding the performance of the various provisioning regimes, is the stock smoothing effect associated with provisions.

\footnotetext{
${ }^{27}$ A more formal analysis based on asymptotic variances (as in Table 2) confirms this result. We do not report the table (neither here nor for $\omega_{L R}>0$ ) to save space.
} 


\section{Monetary Policy and Provisioning Regimes}

Finally, we consider a different but related experiment-whether an augmented monetary policy rule, which takes into account the behavior of credit gaps, coupled with a dynamic provisioning system, can lead to even better results in terms of minimizing a central bank loss function compared to a specific provisioning regime, coupled or not with a similar augmented rule. Rules of this type have been recently advocated by a number of observers and have been viewed as consistent with a broader mandate for central banks concerned with financial stability. ${ }^{28}$

For this purpose the standard Taylor rule (29) is replaced by the augmented Taylor rule

$$
\frac{1+i_{t}^{R}}{1+\tilde{\imath}^{R}}=\left(\frac{1+i_{t-1}^{R}}{1+\tilde{\imath}^{R}}\right)^{\phi}\left[\left(\frac{Y_{t}}{\tilde{Y}}\right)^{\phi_{Y}}\left(\frac{\pi_{t}}{\pi^{T}}\right)^{\phi_{\pi}}\left(\frac{L_{t}^{I} / Y_{t}}{\tilde{L}^{I} / \tilde{Y}}\right)^{\phi_{L}}\right]^{1-\phi},
$$

where $\phi_{L}>0$ denotes the weight given to fluctuations in the credit-to-GDP ratio from its steady-state level. Thus, the central bank sets its policy rate also in part to "lean against the financial cycle." During an expansionary period for instance, when collateral values are high, the loan rate falls. This, in turn, stimulates loans to capital producers and raises the credit-to-output ratio. With rule (34), the policy rate will rise and mitigate the initial decline in the lending rate, thereby dampening the expansion in credit. Because the bond rate will tend to increase as well, it will attenuate an increase in current consumption through the intertemporal substitution effect. Thus, in this setting an augmented Taylor rule helps to mitigate the inherent procyclical nature of the financial system.

To study optimal policy responses, we consider two alternative policy loss functions for the central bank:

$$
\begin{gathered}
L_{t}^{1}=V\left(\hat{\pi}_{t}\right)+0.25 V\left(\hat{Y}_{t}\right), \\
L_{t}^{2}=V\left(\hat{\pi}_{t}\right)+0.25 V\left(\hat{Y}_{t}\right)+0.1 V\left(\hat{L}_{t}-\hat{Y}_{t}\right),
\end{gathered}
$$

where $V\left(x_{t}\right)$ denotes the volatility (as measured by the asymptotic variance) of deviations of $x_{t}$ from its steady state. Equation (35) takes a fairly standard form, with the relative weight attached to the volatility of output deviations being significantly lower than the weight attached to the volatility of inflation deviations from target. The weight of 0.25 on output volatility used here has been used also in a number of other

\footnotetext{
${ }^{28}$ See, for instance, Agénor and Pereira da Silva (2012) and the references therein.
} 
contributions in the literature (see, for instance, Walsh (2003)). Equation (35) augments the loss function to account for the fact that the central bank is also concerned with financial stability, as measured in terms of the volatility of the credit-to-GDP ratio - a robust leading indicator of financial crises, as demonstrated in a number of studies (see, for instance, Gourinchas and Obstfeld (2012) and Schularick and Taylor (2012)). At the same time, as in some other studies (for instance Angelini et al. (2014)) we assume that the weight attached to financial stability is relatively small. The central bank remains therefore mainly concerned with macroeconomic stability.

Assuming as in the benchmark case that $\rho_{L R}=0.8$ and $\omega_{L R}=0$, we compute the loss functions (35) and (36) under four different policy regimes. Under Regime A, we consider a specific provisioning system $(\lambda=0)$ and a standard Taylor rule; we solve for the optimal response to inflation, $\phi_{\pi}$, in the Taylor rule and keep $\phi_{Y}=0.2$ and $\phi_{L}=0$. Under Regime $B$, we consider again a specific provisioning system $(\lambda=0)$ and solve now for both the optimal response to inflation, $\phi_{\pi}$, and the optimal response to the loan-to-output ratio, $\phi_{L}$, in the augmented Taylor rule, while keeping $\phi_{Y}=0.2$. Under Regime $C$, we solve for the optimal value of $\phi_{\pi}$ only and set $\phi_{L}=0$, but we consider a dynamic provisioning regime and solve for the optimal value of the smoothing parameter $\lambda$ in the interval $(0,1)$ that characterizes that regime. Under Regime $D$, we solve for the optimal values of $\phi_{\pi}, \phi_{L}$, as well as $\lambda$ in the interval $(0,1)$. The key issue that we want to address is the following: is it optimal to combine a specific or dynamic provisioning system with a credit gap-augmented Taylor rule to mitigate real and financial volatility? Equivalently, does Regime D dominate the other regimes in terms of minimizing central bank losses, as defined in (35) or (36)? Or would a country be better off sticking to a specific provisioning system and pursuing a more aggressive monetary policy, implying instead that Regime B dominates the other regimes?

Table 3 shows the results of these experiments, using a grid step of 0.1 and assuming that the upper bound of the search for $\phi_{\pi}$ is set at 3 (a reasonable value, given the evidence on confidence intervals associated with point estimates of that parameter) and no upper bound for $\phi_{L}$. They indicate that it is always optimal to respond strongly to inflation - a not so surprising result, given that output and inflation move in the same direction following negative credit shocks. There is a role for an augmented monetary policy that responds also to deviations in the loan-to-output ratio; however, comparing 
Regime $\mathrm{B}$ with regimes $\mathrm{C}$ or $\mathrm{D}$, for which the optimal value of $\lambda$ is 1 in both cases, this role is mitigated when dynamic provisions are implemented. The policy rate rule does not need to respond as strongly to financial conditions. Overall, the best policy appears to be a combination of dynamic provisions (with full smoothnig) and an augmented Taylor rule, regardless of whether a financial stability objective is accounted for or not in the central bank's loss function. Moreover, the combination of a standard interest rate rule and a dynamic provisioning regime with full smoothing performs better than a credit-augmented interest rate rule with specific provisions.

Clearly, more thorough experiments along the same lines are needed to establish firm conclusions. In particular, a wider range of shocks could be considered, and alternative measures of financial stability (involving interest rate spreads, asset prices, and so on) could be defined. Given the length of this paper, these issues would be best pursued in future work. Nevertheless, a tentative conclusion from the experiments reported here is that the combination of an augmented Taylor rule and a dynamic provisioning rule could deliver superior outcomes in terms of macroeconomic and financial stability. At a time when many countries, in the wake of the adoption of the Basel III agreement, are considering the introduction of a variety of countercyclical macroprudential tools, this result - however tentative -is well worth pondering.

\section{Concluding Remarks}

The purpose of this paper was to study the interaction between loan-loss provisions and business cycles in a dynamic stochastic general equilibrium model with credit market imperfections. A key distinction is between specific and dynamic provisioning systems. In the former, provisions are triggered by past due payments (or the fraction of nonperforming loans), which, in turn, depend on current economic conditions and the loan-loss reserves-loan ratio. Dynamic provisioning, by contrast, take into account both past due payments and expected losses over the whole business cycle; provisions are thus smoothed over the cycle and are less affected by the current state of the economy and past due payments. The solution of the model shows that the type of provisioning system and the fraction of nonperforming loans influence directly the behavior of the loan rate, which in turn determine the degree of cyclicality of financial and real variables in the economy. Numerical experiments with a parameterized 
version showed that a dynamic loan-loss provisioning regime can be highly effective in mitigating procyclicality of the financial system. Sensitivity analysis confirmed these results. Finally, we also showed that the combination of a credit gap-augmented Taylor rule and a dynamic provisioning system with full smoothing may be the most effective way to mitigate real and financial volatility. In addition, the combination of a standard Taylor rule and a dynamic provisioning regime with full smoothing performs better than a credit-augmented rule combined with specific provisions. These results have potentially important implications for the ongoing debate on the performance of loan-loss provisioning systems, and more generally on the combination of monetary policy and macroprudential rules.

The analysis in this paper can be extended in several directions. First, the focus of this paper has been mainly on the direct, cost effect of loan-loss provisions. However, another channel that could be explored is the extent to which these provisions may help to mitigate incentives for risk taking by lenders, and the extent to which this could contribute to reducing balance sheet vulnerabilities - thereby reducing their probability of default. Bushman and Williams (2012) for instance, in a study of bank behavior across 27 countries, found that dynamic provisioning reflecting timely recognition of expected future loan losses is associated with enhanced risk-taking discipline.

Second, it would be useful to model simultaneously capital requirement regimes (possibly including a capital buffer, in line with the Basel III Accord) and loan-loss provisioning systems and study how they interact. The common view is that (regular) bank capital should cover for unexpected credit losses, whereas (dynamic) loan-loss provisions are intended to cover expected credit losses. However, in practice capital buffers may well be considered as an alternative to dynamic provisions. In addition, and consistent with the Lucas critique, introducing either one of those regulatory regimes while the other is present may change the behavior of banks and thus the effectiveness of both types of tools. This may occur if the reasons why banks hold (excess) capital buffers are altered by the introduction of loan-loss provisions, and if capital buffers have a signaling effect that translates into changes in their market borrowing costs (as in Agénor et al. (2012) for instance). Put differently, voluntary capital buffers may be (partial) substitutes for provisions. Thus, understanding the interaction between bank capital requirements and dynamic provisioning systems - and possibly the optimal 
combination of these tools to mitigate procyclicality - should be high on the research agenda. 


\section{References}

Agénor, Pierre-Richard, and Koray Alper, "Monetary Shocks and Central Bank Liquidity with Credit Market Imperfections," Oxford Economic Papers, 64 (July 2012), 563-591.

Agénor, Pierre-Richard, Koray Alper, and Luiz Pereira da Silva, "Capital Requirements and Business Cycles with Credit Market Imperfections," Journal of Macroeconomics, 34 (September 2012), 687-705.

_ _ "Capital Regulation, Monetary Policy and Financial Stability," International Journal of Central Banking, 9 (September 2013), 193-238.

Agénor, Pierre-Richard, and Luiz Pereira da Silva, "Macroeconomic Stability, Financial Stability, and Monetary Policy Rules," International Finance, 15 (September 2012), 205-24.

Angelini, Paolo, Stefano Neri, and Fabio Panetta, "Monetary and Macroprudential Policies," Journal of Money, Credit and Banking, 46 (September 2014), 1073-112.

Athanasoglou, Panayiotis P., Ioannis Daniilidis, and Manthos D. Delis, "Bank Procyclicality and Output: Issues and Policies," Journal of Economics and Business, 72 (March 2014), 58-83.

Balla, E., M Rose, and J Romero, "Loan-Loss Reserve Accounting and Bank Behavior," Economic Brief No. 12-03, Federal Reserve Bank of Richmond (March 2012).

Barth, James R., Gerard Caprio Jr, and Ross Levine, "Bank Regulation and Supervision: What Works Best?," Journal of Financial Intermediation, 13 (June 2004), 205-48.

Basel Committee on Banking Supervision, "Basel III: A Global Regulatory Framework for more Resilient Banks and Banking Systems," Report No. 189 (revised, June 2011).

Basel Committee on Banking Supervision, "Models and Tools for Macroprudential Analysis," Working Paper No. 21, Bank for International Settlements (May 2012).

Beatty, Anne, and Scott Liao, "Do Delays in Expected Loss Recognition Affect Banks' Willingness to Lend?," Journal of Accounting and Economics, 52 (June 2011), 1-20.

Bikker, Jacob A., and Paul A. Metzemakers, "Bank Provisioning behavior and Procyclicality," Journal of International Financial Markets, Institutions and Money, 15 (March 2005), 141-57.

Bouvatier, Vincent, and Laetitia Lepetit, "Provisioning Rules and Bank Lending: A Theoretical Model," Journal of Financial Stability, 8 (January 2012), 25-31.

Bushman, Robert M., and Christopher D. Williams, "Accounting Discretion, Loan-Loss Provisioning, and Discipline of Banks' Risk-Taking," Journal of Accounting and Economics, 54 (August 2012), 1-18.

Calvo, Guillermo A., "Staggered Prices in a Utility-Maximizing Framework," Journal of Monetary Economics, 12 (June 1983), 383-98.

Caprio, Gerard Jr., "Safe and Sound Banking: A Role for Countercyclical Regulatory Requirements?," Policy Research Working Paper No. 5198, World Bank (February 2010).

Cashin, Paul, and Rupa Duttagupta, "The Anatomy of Banking Crises," Working Paper No. 08/93, International Monetary Fund (April 2008).

Cavallo, Michele, and Giovanni Majnoni, "Do Banks Provision for Bad Loans in Good Times? Empirical Evidence and Policy Implications," in Ratings, Rating Agencies and the Global Financial System, ed. by Richard M. Levich, Giovanni Majnoni, and 
Carmen M. Reinhart, Series on Financial Markets and Institutions, Vol. 9, New York University Salomon Center (New York: 2002).

Cole, Rebel A., and Lawrence J. White, "Déjà Vu all over Again: The Causes of US Commercial Bank Failures this Time Around," Journal of Financial Services Research, 42 (October 2012), 5-29.

Coleman, Anthony D., Neil Esho, and Ian G. Sharpe, "Does Bank Monitoring Influence Loan Contract Terms?," Journal of Financial Services Research, 30 (October 2006), 177-98.

Davis, E. Philip, and Haibin Zhu, "Commercial Property Prices and Bank Performance," Quarterly Review of Economics and Finance, 49 (November 2009), 1341-59.

Drehmann, Mathias, Claudio Borio, Leonardo Gambacorta, Gabriel Jimenez and Carlos Trucharte, "Countercyclical Capital Buffers: Exploring Options," Working Paper No. 317, Bank for International Settlements (July 2010).

Fernández de Lis, Santiago, and Alicia Garcia-Herrero, "Dynamic Provisioning: A Buffer rather than a Countercyclical Tool?," Economia, 13 (March 2013), 35-60.

Gerali, Andrea, Stefano Neri, Luca Sessa, and Federico M. Signoretti, "Credit and Banking in a DSGE Model of the Euro Area," Journal of Money, Credit, and Banking, 42 (September 2010), 107-41.

Gourinchas, Pierre-Olivier, and Maurice Obstfeld, "Stories of the Twentieth Century for the Twenty-First," American Economic Journal: Macroeconomics, (March 2012), 22665.

Hou, Han, Su-Yin Cheng, and Chin-Pingx Yu, "Life Insurance and Euro Zone's Economic Growth," Procedia-Social and Behavioral Sciences, 57 (October 2012), 126-31.

Jiménez, Gabriel, Steven Ongena, José-Luis Peydró, and Jesus Saurina, "Macroprudential Policy, Countercyclical Bank Capital Buffers and Credit Supply: Evidence from the Spanish Dynamic Provisioning Experiment," Working Paper No. 231, National Bank of Belgium (June 2012).

Jin, Justin Yiqiang, Kiridaran Kanagaretnam, and Gerald J. Lobo, "Ability of Accounting and Audit Quality Variables to Predict Bank Failure during the Financial Crisis," Journal of Banking and Finance, 35 (November 2011), 2811-19.

Demirguc-Kunt, Asli, and Enrica Detragiache, "Cross-Country Empirical Studies of Systemic Bank Distress: A Survey," National Institute Economic Review, 192 (April 2005), 68-83.

Laeven, Luc, and Giovanni Majnoni, "Loan-Loss Provisioning and Economic Slowdowns: Too much, too Late?," Journal of Financial Intermediation, 12 (April 2003), 178-97.

Levine, Ross, Norman Loayza, and Thorsten Beck, "Financial Intermediation and Growth: Causality and Causes," Journal of Monetary Economics, 46 (August 2000), 31-77.

Ng, Jeffrey, and Sugata Roychowdhury, "Loan-Loss Reserves, Regulatory Capital, and Bank Failures: Evidence from the 2008-2009 Economic Crisis," unpublished, MIT Sloan School of Management (June 2011).

Nkusu, Mwanza, "Nonperforming Loans and Macrofinancial Vulnerabilities in Advanced Economies," Working Paper No. 11/161, International Monetary Fund (July 2011).

OECD, National Accounts at a Glance 2010, OECD Publishing (Paris: 2011).

Packer, Frank, and Haibin Zhu, "Loan-Loss Provisioning Practices of Asian banks," Working Paper No 375, Bank for International Settlements (April 2012). 
Perez, Daniel, Vicente Salas-Fumas, and Jesus Saurina, "Earnings and Capital Management in Alternative loan-loss provision Regulatory Regimes," European Accounting Review, 17 (October 2008), 423-45.

Repullo, Rafael, and Jesús Saurina, "The Countercyclical Capital Buffer of Basel III: A Critical Assessment," unpublished, Bank of Spain (March 2011).

Saurina, Jesús, "Dynamic Provisioning: The Experience of Spain," Crisis Response Note No. 7, International Finance Corporation (July 2009).

Schularick, Moritz, and Alan M. Taylor, "Credit Booms Gone Bust: Monetary Policy, Leverage Cycles, and Financial Crises, 1870-2008," American Economic Review, 102 (June 2012), 1029-61.

Shrieves, Ronald E., and Drew Dahl, "The Relationship between Risk and Capital in Commercial Banks," Journal of Banking and Finance, 16 (April 1992), 439-57.

Song, Inwon, "Collateral in Loan Classification and Provisioning," Working Paper No. 02/122, International Monetary Fund (July 2002).

Suh, Hyunduk, "Simple, Implementable Optimal Macroprudential Policy," unpublished, Indiana University (October 2011).

Walsh, Carl, "Speed Limit Policies: The Output Gap and Optimal Monetary Policy," American Economic Review, 93 (March 2003), 265-78.

Walter, John, "Loan Loss Reserves," Federal Reserve Bank of Richmond, Economic Review, 77 (July 1991), 20-30.

Wezel, Torsten, "Dynamic Loan Loss Provisions in Uruguay: Properties, Shock Absorption Capacity and Simulations using Alternative Formulas," Working Paper No. 10/125, International Monetary Fund (May 2010).

Wezel, Torsten, Jorge A. Chan-Lau, and Francesco Columba, "Dynamic Loan Loss Provisioning: Simulations on Effectiveness and Guide to Implementation," Working Paper No. 12/110, International Monetary Fund (May 2012). 


\section{Acknowledgements}

We are grateful to Koray Alper, Luiz Pereira da Silva, William J. Tayler and three anonymous referees for very helpful discussions and comments on a previous draft. Appendices A, B and C are available upon request. 
Table 1

Benchmark Parameterization: Parameter Values

\begin{tabular}{lll}
\hline \hline Parameter & Value & Description \\
\hline$\beta$ & 0.99 & Discount factor \\
$\varsigma^{-1}$ & 0.50 & Elasticity of intertemporal substitution \\
$\gamma$ & 2.50 & Inverse of the Frisch elasticity of labor supply \\
$\eta_{x}$ & 0.01 & Preference parameter for liquidity holdings \\
$v$ & 0.40 & Share Parameter in index of money holdings \\
$\theta_{p}$ & 6.00 & Elasticity of demand for intermediate goods \\
$\omega_{p}$ & 0.75 & Degree of price stickiness \\
$\alpha$ & 0.30 & Share of capital in Intermediate goods output \\
$\delta_{K}$ & 0.03 & Depreciation rate of capital \\
$\Theta_{K}$ & 10.0 & Adjustment cost parameter for investment \\
$j_{0}$ & 0.03 & Steady-state fraction of nonperforming loans \\
$\omega_{Y}$ & 0.20 & Elasticity of fraction of nonperforming loans wrt output gap \\
$\omega_{L R}$ & 0.00 & Elasticity of fraction of nonperforming loans wrt to LLR-loan ratio \\
$\rho_{L R}$ & 0.80 & Persistence parameter in LLR \\
$v^{J}$ & 0.80 & Persistence parameter, financial shock \\
$l_{0}$ & 1.00 & Loan-loss provisions coverage ratio \\
$\lambda$ & 0.80 & Smoothing coefficient in dynamic provisioning rule \\
$\mu$ & 0.30 & Share of government spending in output \\
$\phi$ & 0.80 & Degree of persistence in Taylor rule \\
$\phi_{\pi}$ & 1.50 & Response of policy rate to inflation deviations \\
$\phi_{Y}$ & 0.20 & Response of policy rate to output deviations \\
\hline \hline
\end{tabular}


Table 2

Changes in Standard Deviations of Key Variables under

Specific and Dynamic Provisioning Systems with $\rho_{L R}=0.80$ and $\omega_{L R}=0.0$

\begin{tabular}{c|c|c|cc|cc}
\hline \hline & $\lambda=0$ & $\lambda=0.5$ & Rel. S.D. & $\lambda=0.8$ & Rel. S.D. \\
\hline \hline Output & 0.1946 & & 0.1441 & 0.7404 & 0.1157 & 0.5945 \\
Investment & 1.0585 & & 0.7858 & 0.7423 & 0.6314 & 0.5965 \\
Consumption & 0.1099 & & 0.0900 & 0.8189 & 0.0799 & 0.7270 \\
Price Inflation & 0.0689 & 0.0518 & 0.7518 & 0.0174 & 0.2525 \\
Loan Rate & 0.7120 & 0.5977 & 0.8394 & 0.5344 & 0.7505 \\
Fraction of nonperforming loans & 16.7016 & 16.693 & 0.9994 & 15.463 & 0.9258 \\
Marginal Cost & 0.5809 & 0.3977 & 0.6846 & 0.2889 & 0.4973 \\
Bond Rate & 0.0454 & 0.0364 & 0.8017 & 0.0316 & 0.6960 \\
Loan-Output Ratio & 0.8687 & 0.6464 & 0.7441 & 0.5207 & 0.5994 \\
LLP-Loan Ratio & 16.7016 & 8.3465 & 0.4997 & 3.3376 & 0.1998 \\
\hline \hline
\end{tabular}


Table 3

Central Bank Losses and Optimal Policy Parameters, Financial Shock

\begin{tabular}{lll}
\hline \hline & Loss Function $L_{t}^{1}$ & Loss Function $L_{t}^{2}$ \\
\hline \hline & $\phi_{\pi}=3$ & $\phi_{\pi}=3$ \\
Regime A & $\phi_{L}=-$ & $\phi_{L}=-$ \\
& $\lambda=-$ & $\lambda=-$ \\
& $L^{1}=0.0102$ & $L^{2}=0.0747$ \\
\hline \hline & $\phi_{\pi}=3$ & $\phi_{\pi}=3$ \\
Regime B & $\phi_{L}=0.4$ & $\phi_{L}=1.4$ \\
& $\lambda=-$ & $\lambda=-$ \\
& $L^{1}=0.0033$ & $L^{2}=0.0241$ \\
\hline \hline & $\phi_{\pi}=3$ & $\phi_{\pi}=3$ \\
Regime $\mathrm{C}$ & $\phi_{L}=-$ & $\phi_{L}=-$ \\
& $\lambda=1$ & $\lambda=1$ \\
& $L^{1}=0.0023$ & $L^{1}=0.0191$ \\
\hline \hline & $\phi_{\pi}=3$ & $\phi_{\pi}=3$ \\
Regime D & $\phi_{L}=0.2$ & $\phi_{L}=0.4$ \\
& $\lambda=1$ & $\lambda=1$ \\
& $L^{1}=0.0014$ & $L^{2}=0.0132$ \\
\hline \hline
\end{tabular}

Notes: Entries shown for the loss functions are absolute values. 
Figure 1

Experiment: Transitory Increase in Nonperforming Loans Benchmark Case: $\rho_{L R}=0.8$ and $\omega_{L R}=0$
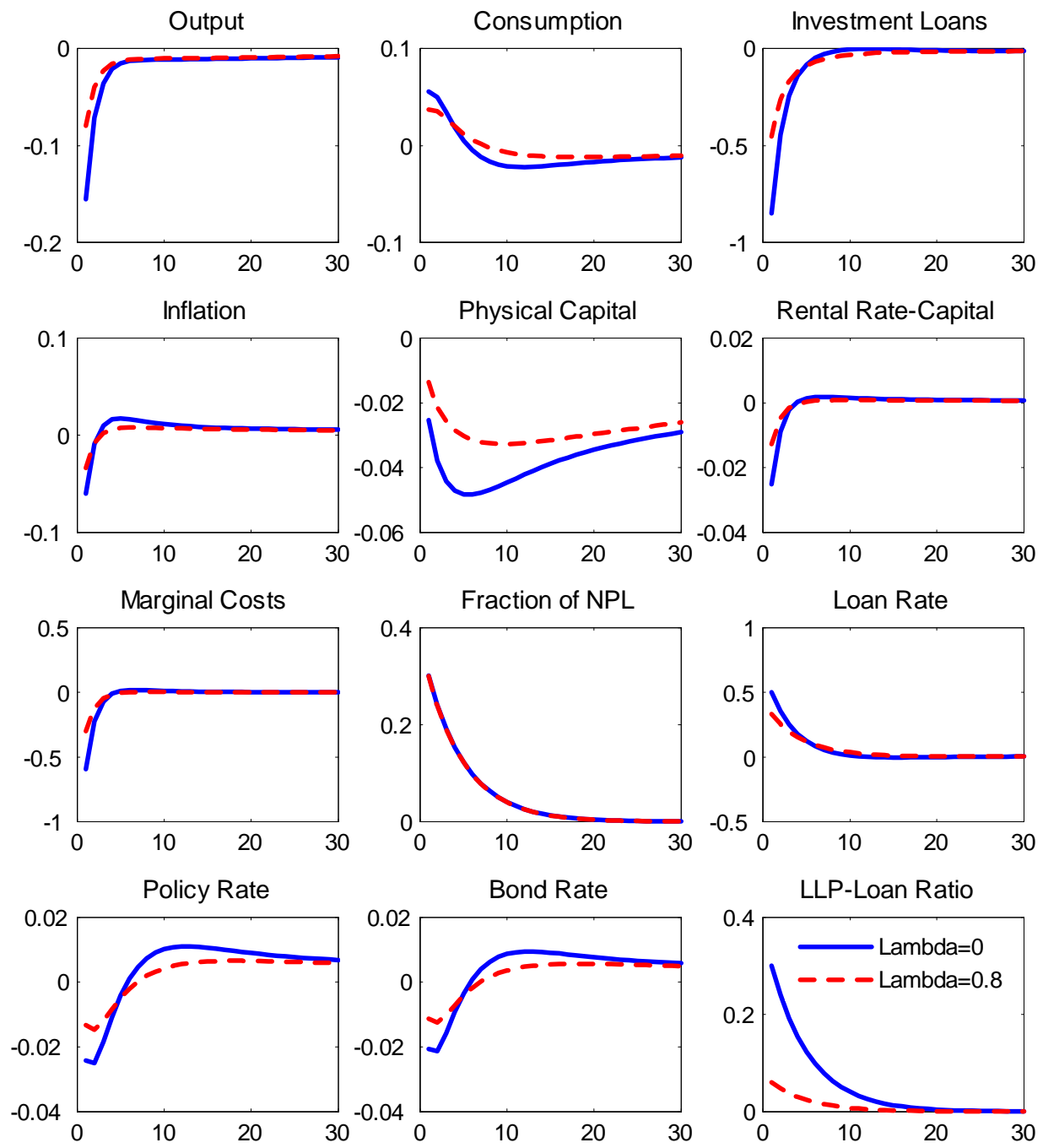
Figure 2

Experiment: Transitory Increase in Nonperforming Loans Alternative Values: $\rho_{L R}=0.95$ and $\omega_{L R}=0$
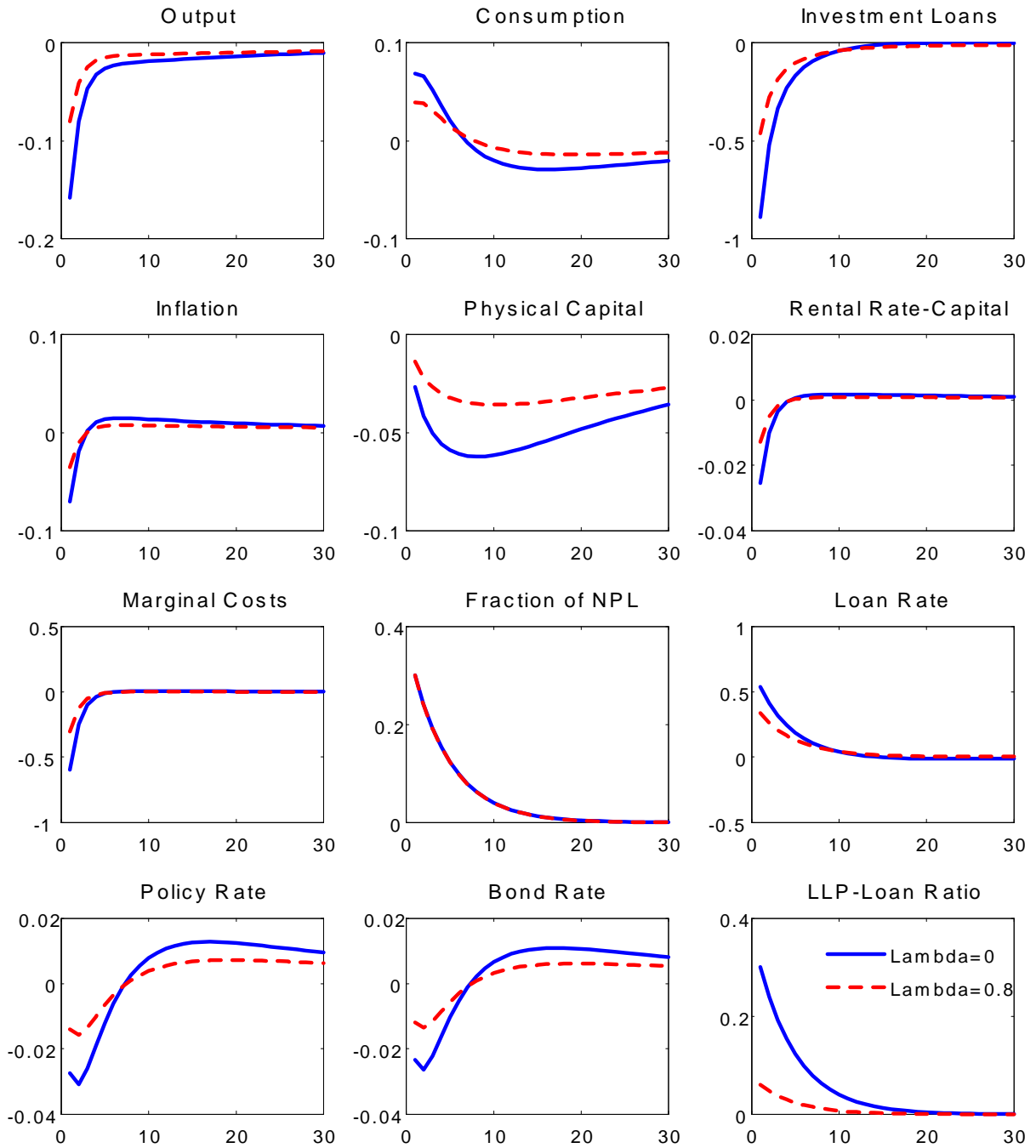
Figure 3

Experiment: Transitory Increase in Nonperforming Loans Alternative Values: $\rho_{L R}=0.15$ and $\omega_{L R}=0$
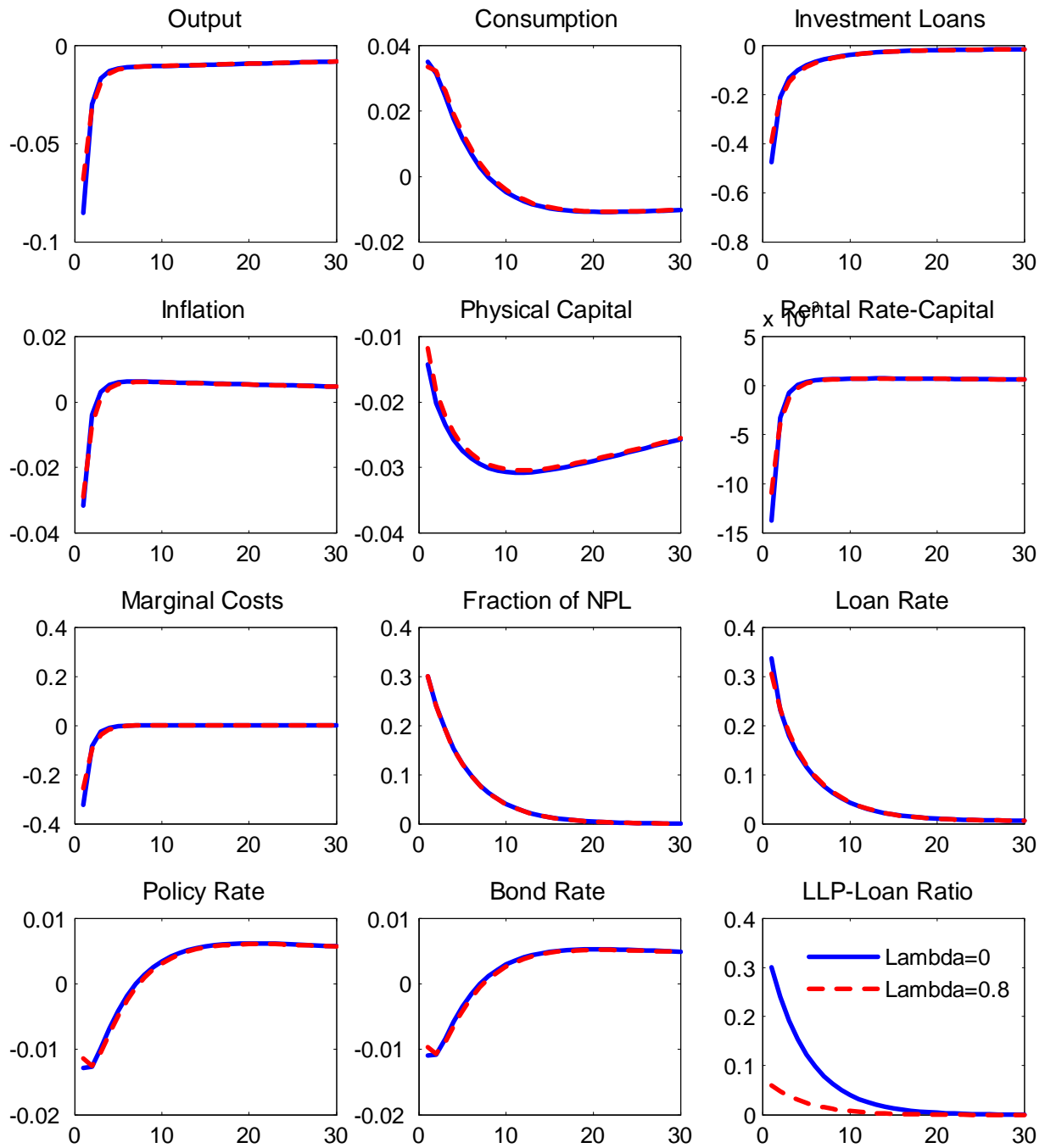
Figure 4

Experiment: Transitory Increase in Nonperforming Loans

Alternative Values: $\rho_{L R}=0.80$ and $\omega_{L R}=-0.15$
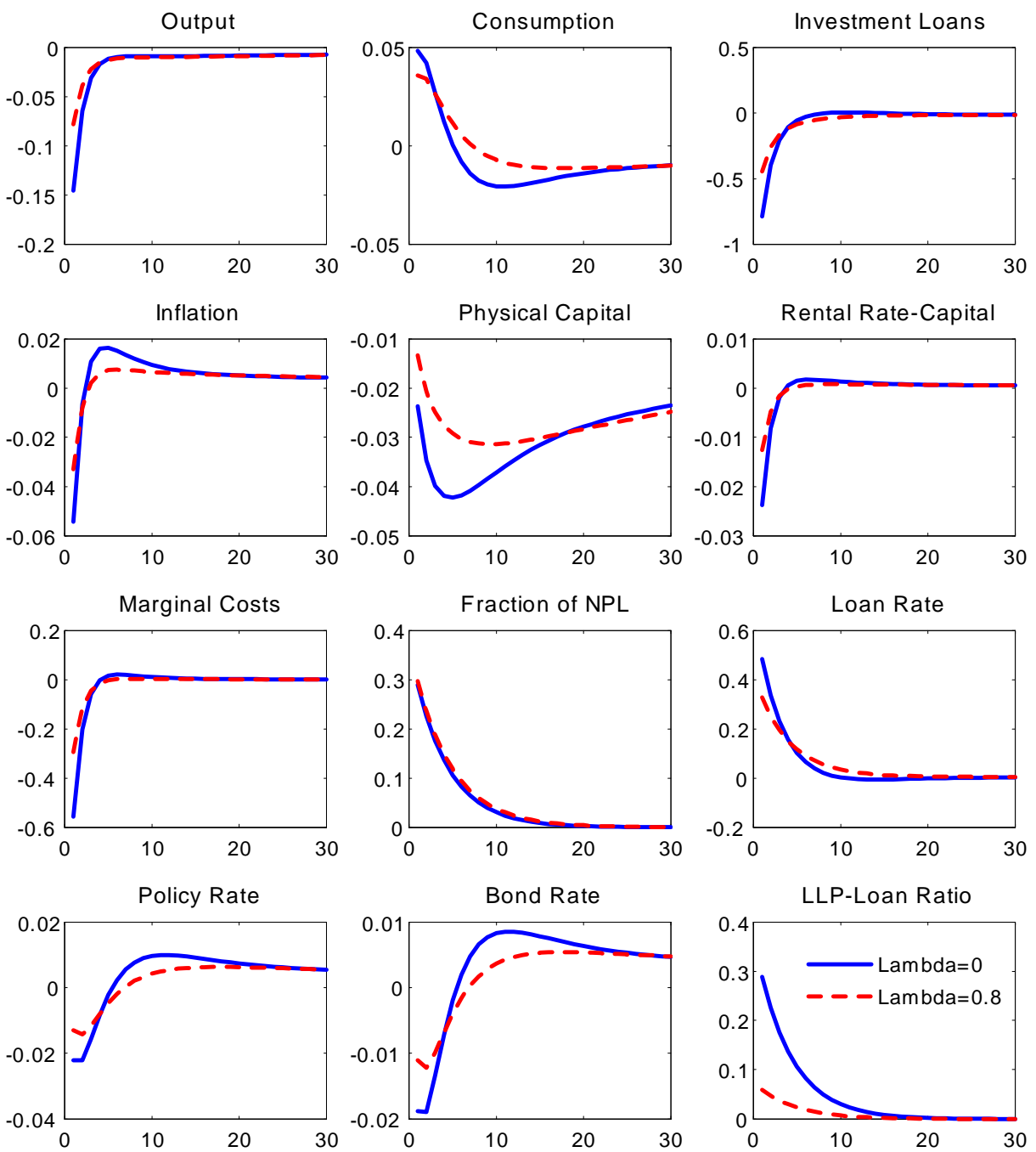
Figure 5

Experiment: Transitory Increase in Nonperforming Loans Alternative Values: $\rho_{L R}=0.80$ and $\omega_{L R}=0.15$
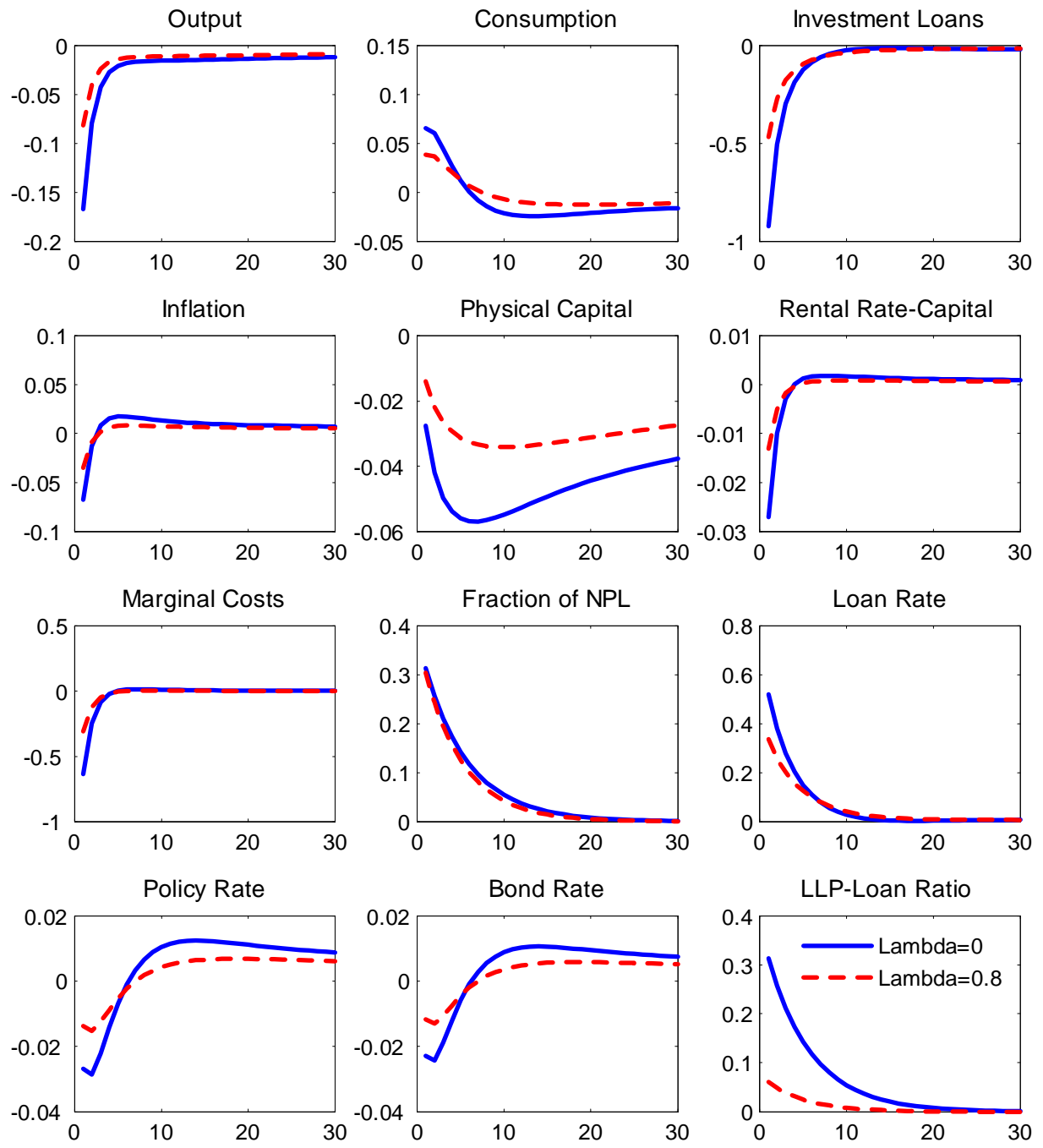


\section{Appendix A \\ Derivation of the Rental Rate of Capital}

The stock of capital goods, $K_{t+1}$, evolves as

$$
K_{t+1}=I_{t}+(1-\delta) K_{t}-\frac{\Theta_{K}}{2}\left(\frac{K_{t+1}}{K_{t}}-1\right)^{2} K_{t},
$$

The CG producer chooses the level of capital stock so as to maximize the value of the discounted stream of dividend payments to households subject to (A1). Specifically, define expected end-of-period real profits of the CG producer as

$$
\mathbb{E}_{t} J_{t+1}^{K}=r_{t}^{K} K_{t}-J_{t} \kappa K_{t}-\left(1-J_{t}\right)\left(1+i_{t}^{L}\right) L_{t}^{I} .
$$

Using (A1) to substitute out for $I_{t}$ in the above expression, the optimization problem takes the form

$$
\begin{gathered}
\max _{K_{t+s+1}} \mathbb{E}_{t} \sum_{s=0}^{\infty} \beta^{s} \varphi_{t+s}\left\{r_{t+s}^{K} K_{t+s}-J_{t+s} \kappa K_{t+s}\right. \\
\left.-\left(1-J_{t+s}\right)\left(1+i_{t+s}^{L}\right)\left[K_{t+s+1}-\left(1-\delta_{K}\right) K_{t+s}+\frac{\Theta_{K}}{2}\left(\frac{K_{t+s+1}}{K_{t+s}}-1\right)^{2} K_{t+s}\right]\right\} .
\end{gathered}
$$

taking $J_{t}$ and $i_{t}^{L}$ as given.

The first-order condition with respect to $K_{t+1}$ yields,

$$
\begin{gathered}
\beta \varphi_{t+1} r_{t+1}^{K}-\varphi_{t}\left(1-J_{t}\right)\left(1+i_{t}^{L}\right)+\beta \varphi_{t+1}\left(1-J_{t+1}\right)\left(1+i_{t+1}^{L}\right)(1-\delta) \\
-\varphi_{t}\left(1-J_{t}\right)\left(1+i_{t}^{L}\right) \Theta_{K}\left(\frac{K_{t+1}}{K_{t}}-1\right) \frac{K_{t}}{K_{t}}-\beta \varphi_{t+1} J_{t+1} \kappa \\
-\beta \varphi_{t+1}\left(1-J_{t+1}\right)\left(1+i_{t+1}^{L}\right)\left\{\frac{\Theta_{K}}{2}\left(\frac{K_{t+2}}{K_{t+1}}-1\right)^{2}-\Theta_{K}\left(\frac{K_{t+2}}{K_{t+1}}-1\right) \frac{K_{t+2}}{K_{t+1}^{2}} K_{t+1}\right\}=0 .
\end{gathered}
$$

Expanding terms

$$
\begin{gathered}
\beta \varphi_{t+1} r_{t+1}^{K}-\varphi_{t}\left(1-J_{t}\right)\left(1+i_{t}^{L}\right)+\beta \varphi_{t+1}\left(1-J_{t+1}\right)\left(1+i_{t+1}^{L}\right)(1-\delta) \\
-\varphi_{t}\left(1-J_{t}\right)\left(1+i_{t}^{L}\right) \Theta_{K}\left(\frac{K_{t+1}}{K_{t}}\right)+\varphi_{t}\left(1-J_{t}\right)\left(1+i_{t}^{L}\right) \Theta_{K}-\beta \varphi_{t+1} J_{t+1} \kappa \\
\left.-\beta \varphi_{t+1}\left(1-J_{t+1}\right)\left(1+i_{t+1}^{L}\right) \frac{\Theta_{K}}{2}\left(\frac{K_{t+2}}{K_{t+1}}\right)^{2}+\beta \varphi_{t+1}\right)\left(1-J_{t+1}\right)\left(1+i_{t+1}^{L}\right) \frac{\Theta_{K}}{2} 2 \frac{K_{t+2}}{K_{t+1}} \\
-\beta \varphi_{t+1}\left(1-J_{t+1}\right)\left(1+i_{t+1}^{L}\right) \frac{\Theta_{K}}{2} \\
+\beta \varphi_{t+1}\left(1-J_{t+1}\right)\left(1+i_{t+1}^{L}\right) \Theta_{K}\left(\frac{K_{t+2}}{K_{t+1}}\right)^{2}-\beta \varphi_{t+1}\left(1-J_{t+1}\right)\left(1+i_{t+1}^{L}\right) \Theta_{K} \frac{K_{t+2}}{K_{t+1}}=0 .
\end{gathered}
$$

Collecting terms,

$$
\beta \varphi_{t+1} r_{t+1}^{K}-\varphi_{t}\left(1-J_{t}\right)\left(1+i_{t}^{L}\right)+\beta \varphi_{t+1}\left(1-J_{t+1}\right)\left(1+i_{t+1}^{L}\right)(1-\delta)-\varphi_{t}\left(1-J_{t}\right)\left(1+i_{t}^{L}\right) \Theta_{K}\left(\frac{K_{t+1}}{K_{t}}\right)
$$




$$
\begin{gathered}
+\varphi_{t}\left(1-J_{t}\right)\left(1+i_{t}^{L}\right) \Theta_{K}-\beta \varphi_{t+1} J_{t+1} \kappa \\
+\beta \varphi_{t+1}\left(1-J_{t+1}\right)\left(1+i_{t+1}^{L}\right) \frac{\Theta_{K}}{2}\left(\frac{K_{t+2}}{K_{t+1}}\right)^{2}-\beta \varphi_{t+1}\left(1-J_{t+1}\right)\left(1+i_{t+1}^{L}\right) \frac{\Theta_{K}}{2}=0
\end{gathered}
$$

or,

$$
\begin{gathered}
\beta \varphi_{t+1} r_{t+1}^{K}=\varphi_{t}\left(1-J_{t}\right)\left(1+i_{t}^{L}\right)\left[1+\Theta_{K}\left(\frac{K_{t+1}}{K_{t}}\right)-\Theta_{K}\right] \\
+\beta \varphi_{t+1}\left\{J_{t+1} \kappa-\left(1-J_{t+1}\right)\left(1+i_{t+1}^{L}\right)\left[1-\delta+\frac{\Theta_{K}}{2}\left(\frac{K_{t+2}}{K_{t+1}}\right)^{2}-\frac{\Theta_{K}}{2}\right]\right\},
\end{gathered}
$$

or again

$$
\begin{gathered}
r_{t+1}^{K}=\frac{\varphi_{t}}{\beta \varphi_{t+1}}\left(1-J_{t}\right)\left(1+i_{t}^{L}\right)\left[1+\Theta_{K}\left(\frac{K_{t+1}}{K_{t}}-1\right)\right] \\
+\left\{J_{t+1} \kappa-\left(1-J_{t+1}\right)\left(1+i_{t+1}^{L}\right)\left\{1-\delta+\frac{\Theta_{K}}{2}\left[\left(\frac{K_{t+2}}{K_{t+1}}\right)^{2}-1\right]\right\}\right\} .
\end{gathered}
$$

From the household's FOCs,

$$
\frac{\varphi_{t}}{\beta \varphi_{t+1}}=\frac{1+i_{t}^{B}}{1+\pi_{t+1}}
$$

Substituting this result above and inserting back the expectations operator yields

$$
\begin{gathered}
\mathbb{E}_{t} r_{t+1}^{K}=\left(1-J_{t}\right)\left(1+i_{t}^{L}\right) \mathbb{E}_{t}\left\{\left[1+\Theta_{K}\left(\frac{K_{t+1}}{K_{t}}-1\right)\right]\left(\frac{1+i_{t}^{B}}{1+\pi_{t+1}}\right)\right\} \\
+\mathbb{E}_{t}\left\{\kappa J_{t+1}-\left(1-J_{t+1}\right)\left(1+i_{t+1}^{L}\right)\left\{1-\delta+\frac{\Theta_{K}}{2}\left[\left(\frac{K_{t+2}}{K_{t+1}}\right)^{2}-1\right]\right\}\right\},
\end{gathered}
$$

which, with $P_{t} / P_{t+1}=1 /\left(1+\pi_{t+1}\right)$, is equation (15) in the text. 


\section{Appendix B \\ Derivation of the Loan Rate and Deposit Rate}

The bank's maximization problem is defined as

$$
\max _{1+i_{t}^{L}, 1+i_{t}^{D}}\left\{\begin{array}{c}
\left(1-J_{t}\right)\left(1+i_{t}^{L}\right) L_{t}^{I}+J_{t} \kappa K_{t}+\left(1+i_{t}^{B}\right) L L R_{t}^{i} \\
-\left(1+i_{t}^{D}\right) D_{t}-\left(1+i_{t}^{R}\right) L_{t}^{B}-L L P_{t}^{i}
\end{array}\right\},
$$

subject to,

$$
\begin{gathered}
L_{t}^{I}=I_{t}, \\
L_{t}^{B}=L_{t}^{I}-D_{t},
\end{gathered}
$$

$$
\begin{aligned}
& L L P_{t}^{i}=l_{0} J_{t} L_{t}^{I} \quad \text { for } i=S \text {, } \\
& L L P_{t}^{i}=l_{0} J_{t} L_{t}^{I}+\lambda\left(\widetilde{J}-J_{t}\right) l_{0} L_{t} \text { for } i=D \text {. } \\
& L L R_{t}=\left(L L R_{t-1}\right)^{\rho_{L R}}\left(L L P_{t}\right)^{1-\rho_{L R}},
\end{aligned}
$$

with $J_{t}$ taken as given.

The first-order condition with respect to $1+i_{t}^{L}$ yields

$$
\begin{gathered}
\left(1-J_{t}\right) L_{t}^{I}+\left(1-J_{t}\right)\left(1+i_{t}^{L}\right) \frac{\partial L_{t}^{I}}{\partial\left(1+i_{t}^{L}\right)} \\
+\left(1+i_{t}^{B}\right) \frac{\partial L L R_{t}}{\partial L_{t}^{I}} \frac{\partial L_{t}^{I}}{\partial\left(1+i_{t}^{L}\right)}-\left(1+i_{t}^{R}\right) \frac{\partial L_{t}^{B}}{\partial L_{t}^{I}} \frac{\partial L_{t}^{I}}{\partial\left(1+i_{t}^{L}\right)} \\
-\left(1+i_{t}^{R}\right) \frac{\partial L_{t}^{B}}{\partial L L R_{t}} \frac{\partial L L R_{t}}{\partial L L P_{t}^{i}} \frac{\partial L P_{t}^{i}}{\partial L_{t}^{I}} \frac{\partial L_{t}^{I}}{\partial\left(1+i_{t}^{L}\right)}-\frac{\partial L L P_{t}^{i}}{\partial L_{t}^{I}} \frac{\partial L_{t}^{I}}{\partial\left(1+i_{t}^{L}\right)}=0
\end{gathered}
$$

Because loan loss reserves are invested in a safe asset $\left(B_{t}=L L R_{t}\right)$ then

$$
\frac{\partial L_{t}^{B}}{\partial L L R_{t}} \frac{\partial L L R_{t}}{\partial L L P_{t}^{i}} \frac{\partial L L P_{t}^{i}}{\partial L_{t}^{I}} \frac{\partial L_{t}^{I}}{\partial\left(1+i_{t}^{L}\right)}=0
$$

Noting that $\partial L_{t}^{B} / \partial L_{t}^{I}=1$ yields

$$
\begin{gathered}
\left(1-J_{t}\right) L_{t}^{I}+\left[1-J_{t}\right]\left(1+i_{t}^{L}\right) \frac{\partial L_{t}^{I}}{\partial\left(1+i_{t}^{L}\right)} \\
+\left(1+i_{t}^{B}\right) \frac{\partial L L R_{t}^{i}}{\partial L_{t}^{I}} \frac{\partial L_{t}^{I}}{\partial\left(1+i_{t}^{L}\right)}-\left(1+i_{t}^{R}\right) \frac{\partial L_{t}^{I}}{\partial\left(1+i_{t}^{L}\right)}-\frac{\partial L L P_{t}^{i}}{\partial L_{t}^{I}} \frac{\partial L_{t}^{I}}{\partial\left(1+i_{t}^{L}\right)}=0,
\end{gathered}
$$

dividing by $L_{t}^{I}$,

$$
\begin{aligned}
\left(1-J_{t}\right)+ & \left(1-J_{t}\right)\left(1+i_{t}^{L}\right) \frac{\partial L_{t}^{I}}{\partial\left(1+i_{t}^{L}\right)} \frac{1}{L_{t}^{I}}+\left(1+i_{t}^{B}\right) \frac{\partial L L R_{t}^{i}}{\partial L_{t}^{I}} \frac{\partial L_{t}^{I}}{\partial\left(1+i_{t}^{L}\right)} \frac{1}{L_{t}^{I}} \\
& -\left(1+i_{t}^{R}\right) \frac{\partial L_{t}^{I}}{\partial\left(1+i_{t}^{L}\right)} \frac{1}{L_{t}^{I}}-\frac{\partial L L P_{t}^{i}}{\partial L_{t}^{I}} \frac{\partial L_{t}^{I}}{\partial\left(1+i_{t}^{L}\right)} \frac{1}{L_{t}^{I}}=0
\end{aligned}
$$


defining $\eta_{L}=\left[\partial L_{t}^{I} / \partial\left(1+i_{t}^{L}\right)\right]\left[\left(1+i_{t}^{L}\right) / L_{t}^{I}\right]$ as the interest elasticity of the loan demand and treating it as a constant, the above reduces to

$$
\begin{gathered}
\left(1-J_{t}\right)+\left(1-J_{t}\right) \eta_{L}+\left(1+i_{t}^{B}\right) \frac{\eta_{L}}{\left(1+i_{t}^{L}\right)} \frac{\partial L L R_{t}^{i}}{\partial L_{t}^{I}} \\
-\left(1+i_{t}^{R}\right) \frac{\eta_{L}}{\left(1+i_{t}^{L}\right)}-\frac{\partial L L P_{t}^{i}}{\partial L_{t}^{I}} \frac{\eta_{L}}{\left(1+i_{t}^{L}\right)}=0
\end{gathered}
$$

multiplying by $1+i_{t}^{L}$,

$$
\begin{gathered}
\left(1-J_{t}\right)\left(1+i_{t}^{L}\right)+\left(1-J_{t}\right) \eta_{L}\left(1+i_{t}^{L}\right) \\
+\left(1+i_{t}^{B}\right) \frac{\partial L L R_{t}^{i}}{\partial L_{t}^{I}}-\left(1+i_{t}^{R}\right) \eta_{L}-\frac{\partial L L P_{t}^{i}}{\partial L_{t}^{I}} \eta_{L}=0
\end{gathered}
$$

or,

$$
\frac{1-J_{t}}{\left(1+\eta_{L}\right)^{-1}}\left(1+i_{t}^{L}\right)=\eta_{L}\left\{\left(1+i_{t}^{R}\right)+\frac{\partial L L P_{t}^{i}}{\partial L_{t}^{I}}-\left(1+i_{t}^{B}\right) \frac{\partial L L R_{t}^{i}}{\partial L_{t}^{I}}\right\},
$$

which is equation (24) in the text. 


\section{Appendix C \\ Log-Linearized Equations}

The log-linearized equations of the model are based on the steady-state solutions and represent percentage point deviations for price inflation, wage inflation and interest rate variables, and log-deviations around a non-stochastic steady state for the rest of the variables. ${ }^{30}$ The log-linearized variables, denoted with hats, are listed below.

The Euler equation,

$$
\widehat{C}_{t}=\mathbb{E}_{t} \widehat{C_{t+1}}-\varsigma\left(\widehat{i_{t}^{B}}-\mathbb{E}_{t} \widehat{\pi_{t+1}^{P}}\right)
$$

Deposits,

$$
\widehat{D_{t}}=\varsigma \widehat{C}_{t}+\frac{1+\tilde{\imath}^{D}}{\left(\tilde{\imath}^{B}-\tilde{\imath}^{D}\right)}\left(\widehat{i_{t}^{D}}-\widehat{i_{t}^{B}}\right) .
$$

Household real money balances,

$$
\widehat{M_{t}^{H}}=\varsigma \widehat{C}_{t}-\left(\frac{\beta}{1-\beta}\right) \widehat{i_{t}^{B}}
$$

Real wages,

$$
\widehat{W_{t}^{R}}=\gamma \widehat{H_{t}}+\varsigma \widehat{C}_{t} .
$$

Employment (from the production function),

$$
\widehat{N_{t}}=\frac{1}{1-\alpha} \widehat{Y_{t}}-\frac{\alpha}{1-\alpha} \widehat{K_{t}}-\frac{1}{1-\alpha} \widehat{A_{t}}
$$

Capital-labor ratio,

$$
\widehat{K_{t}}-\widehat{N_{t}}=\widehat{W_{t}^{R}}-\frac{\left(1+\tilde{r}^{K}\right)}{\tilde{r}^{K}} \widehat{r}_{t}^{K}
$$

Marginal cost,

$$
\widehat{m c_{t}}=(1-\alpha) \widehat{W_{t}^{R}}+\alpha \frac{\left(1+\tilde{r}^{K}\right)}{\tilde{r}^{K}} \widehat{r}_{t}^{K}-\widehat{A_{t}} .
$$

The New Keynesian Phillips Curve, which determines the price inflation rate, is given by,

$$
\hat{\pi}_{t}=\beta \mathbb{E}_{t} \hat{\pi}_{t+1}+\frac{\left(1-\omega_{p}\right)\left(1-\omega_{p} \beta\right)}{\omega_{p}} \widehat{m c_{t}} .
$$

Investment loans,

$$
\widehat{L_{t}^{I}}=\widehat{I_{t}}
$$

Deposit rate,

$$
\widehat{i_{t}^{D}}=\widehat{i_{t}^{R}}
$$

with $\widehat{i_{t}^{R}}$ defined by the Taylor rule.

\footnotetext{
${ }^{30}$ Therefore, log-linearized net interest rates are used as an approximation for log-linearized gross interest rates.
} 
The rental price of capital,

$$
\begin{gathered}
\left(1+\tilde{r}^{K}\right) \mathbb{E}_{t} \widehat{r_{t+1}^{K}}=(1-\tilde{J})\left(1+\tilde{i}^{L}\right)\left(1+\tilde{i}^{B}\right)\left[\widehat{i_{t}^{L}}+\widehat{i_{t}^{B}}-\mathbb{E}_{t} \widehat{\pi_{t+1}}+\Theta_{K} \mathbb{E}_{t}\left(\widehat{K_{t+1}}-\widehat{K_{t}}\right)\right] \\
-\left(1+\widetilde{i}^{L}\right)\left(1+\widetilde{i}^{B}\right) \widetilde{J} \widehat{J}_{t}-(1-\widetilde{J})\left(1+\widetilde{i}^{L}\right)\left[\left(1-\delta_{K}\right) \widehat{i_{t+1}^{L}}+\Theta_{K} \mathbb{E}_{t}\left(\widehat{K_{t+2}}-\widehat{K_{t+1}}\right)\right] \\
+\left[\kappa+\left(1+\widetilde{i}^{L}\right)\left(1-\delta_{K}\right)\right] \widetilde{J} \mathbb{E}_{t} \widehat{J_{t+1}} .
\end{gathered}
$$

Evolution of capital,

$$
\mathbb{E}_{t} \widehat{K_{t+1}}=\delta_{K} \widehat{I}_{t}+\left(1-\delta_{K}\right) \widehat{K_{t}}
$$

Central bank borrowing,

$$
\widehat{L_{t}^{B}}=\frac{1}{\tilde{L}^{B}}\left\{\tilde{L}^{I} \widehat{L_{t}^{I}}-\left(1-\mu_{D}\right) \tilde{D} \widehat{D_{t}}\right\}
$$

Loan-loss provisions in the specific and dynamic systems are respectively given by,

$$
\begin{gathered}
\widehat{L L P_{t}^{S}}=\widehat{J}_{t}+\widehat{L_{t}^{I}}, \\
\widehat{L L P_{t}^{D}}=(1-\lambda) \widehat{J}_{t}+\widehat{L_{t}^{I}} .
\end{gathered}
$$

The fraction of nonperforming loans in its log-linear form is represented by,

$$
\widehat{J}_{t}=\omega_{Y} \widehat{Y}_{t}+\omega_{L R}\left(\widehat{L L P_{t}^{i}}-\widehat{L_{t}^{I}}\right)+\widehat{\varepsilon_{t}^{J}},
$$

Loan-loss reserves,

$$
\widehat{L L R_{t}^{i}}=\rho_{L R} \widehat{L L R_{t-1}}+\left(1-\rho_{L R}\right) \widehat{L L P_{t}^{i}}
$$

The loan rate,

$$
\begin{gathered}
(1-\tilde{J})\left(1+\tilde{\imath}^{L}\right) \widehat{i_{t}^{L}}=\left(1+\tilde{\imath}^{R}\right) \widehat{i_{t}^{R}}+\left[1-\left(1+\tilde{\imath}^{B}\right)\right] \tilde{J}\left(\frac{\widehat{\partial L L P_{t}^{i}}}{\partial L_{t}^{I}}\right)- \\
-\left(1+\widetilde{i}^{B}\right) \tilde{J}\left[\widehat{i_{t}^{B}}-\rho_{L R}\left(\widehat{L L P_{t}^{i}}-\widehat{L L R_{t-1}}\right)\right]+\tilde{J}\left(1+\tilde{\imath}^{L}\right) \widehat{J}_{t}
\end{gathered}
$$

where $\frac{\partial \overline{L L P_{t}^{S}}}{\partial L_{t}^{I}}=\widehat{J}_{t}$ for the specific provisioning regime and $\left(\frac{\partial L L P_{t}^{D}}{\partial L_{t}^{I}}\right)=(1-\lambda) \widehat{J}_{t}$ for the dynamic provisioning regime.

The goods market equilibrium,

$$
\tilde{Y} \widehat{Y}_{t}=\tilde{C} \widehat{C}_{t}+\tilde{I} \widehat{I}_{t}+\tilde{G} \widehat{G_{t}} .
$$

where $\widehat{G_{t}}=\widehat{Y}_{t}$.

Taxes,

$$
\tilde{T} \widehat{T}_{t}-\tilde{G} \widehat{G_{t}}=\left(1+\tilde{\imath}^{B}\right) B^{H} \widehat{i_{t-1}^{B}}+(\tilde{G}-\tilde{T}-\bar{B}) \widehat{\pi_{t}}-\tilde{\imath}^{R} \tilde{L}^{B} \widehat{L_{t-1}^{B}}-\left(1+\tilde{\imath}^{R}\right) \tilde{L}^{B} \widehat{i_{t-1}^{R}} .
$$

Finally, after the substitutions mentioned in the text, the log-linear money market equilibrium condition, from which $\widehat{i_{t}^{B}}$ is obtained, is given by

$$
\tilde{D} \widehat{D_{t}}+\tilde{M}^{H} \widehat{M_{t}^{H}}=0 \text {. }
$$

